Article

\title{
Establishment of Epidemiological Cut-Off Values and the Distribution of Resistance Genes in Aeromonas hydrophila and Aeromonas veronii Isolated from Aquatic Animals
}

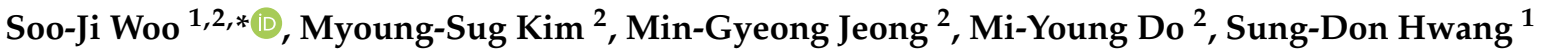 \\ and Woo-Jin Kim ${ }^{1}$
}

check for

updates

Citation: Woo, S.-J.; Kim, M.-S.;

Jeong, M.-G.; Do, M.-Y.; Hwang,

S.-D.; Kim, W.-J. Establishment of

Epidemiological Cut-Off Values and the Distribution of Resistance Genes

in Aeromonas hydrophila and

Aeromonas veronii Isolated from

Aquatic Animals. Antibiotics 2022, 11, 343. https://doi.org/10.3390/ antibiotics 11030343

Academic Editor: Jarl Bøgwald

Received: 13 January 2022

Accepted: 25 February 2022

Published: 5 March 2022

Publisher's Note: MDPI stays neutral with regard to jurisdictional claims in published maps and institutional affiliations.

Copyright: (c) 2022 by the authors. Licensee MDPI, Basel, Switzerland. This article is an open access article distributed under the terms and conditions of the Creative Commons Attribution (CC BY) license (https:/ / creativecommons.org/licenses/by/ $4.0 /)$.
1 Aquaculture Industry Research Division, East Sea Fisheries Research Institute, National Institute of Fisheries Science, Gangneung 25435, Korea; sdhwang@korea.kr (S.-D.H.); wj2464@korea.kr (W.-J.K.)

2 Pathology Research Division, National Institute of Fisheries Science, Busan 46083, Korea; fishdoc@korea.kr (M.-S.K.); susymg@naver.com (M.-G.J.); domiyeong@gmail.com (M.-Y.D.)

* Correspondence: wsj2215@naver.com; Tel.: +82-51-660-8605

Abstract: The emergence of antimicrobial-resistant bacteria is an enormous challenge to public health. Aeromonas hydrophila and Aeromonas veronii are opportunistic pathogens in fish. They exert tremendous adverse effects on aquaculture production, owing to their acquired antibiotic resistance. A few Clinical and Laboratory Standards Institute (CLSI) epidemiological cut-off values (ECVs) against Aeromonas spp. are available. We evaluated antimicrobial susceptibility by establishing 8 ECVs using two analytical methods, normalized resistance interpretation and ECOFFinder. We detected antimicrobial resistance genes in two motile Aeromonas spp. isolated from aquatic animals. Results showed that $89.2 \%$ of $A$. hydrophila and $75.8 \%$ of $A$. veronii isolates were non-wild types according to the oxytetracycline $\mathrm{ECV}_{\mathrm{CLSI}}$ and $\mathrm{ECV}_{\mathrm{NRI}}$, respectively. The antimicrobial resistance genes included tet $A$, tet $B$, tet $D$, tet $E$, cat, floR, qnr $A, q n r B, q n r S$, str $A-\operatorname{str} B$, and $a a c\left(6^{\prime}\right)-1 b$. The most common tet gene in Aeromonas spp. isolates was tet $E$, followed by tet $A$. Some strains carried more than one tet gene, with tet $A-t e t D$ and tet $A-t e t E$ found in $A$. hydrophila; however, tet $B$ was not detected in any of the strains. Furthermore, $18.6 \%$ of $A$. hydrophila and $24.2 \%$ of $A$. veronii isolates showed presumptive multidrug-resistant phenotypes. The emergence of multidrug resistance among aquatic aeromonads suggests the spread of drug resistance and difficult to treat bacterial infections.

Keywords: Aeromonas spp.; antimicrobial resistance gene; ECOFFinder; epidemiological cut-off values; normalized resistance interpretation; MIC

\section{Introduction}

The genus Aeromonas comprises 36 species representing ubiquitous bacteria isolated from food, animal, and aquatic environments [1]. Among the salmonids, the genus Aeromonas is an enteric pathogen, which causes haemorrhagic septicaemia, fin rot, and soft-tissue rot companied by high mortality [2,3]. Aeromonas spp. produce a variety of toxins, including hemolysins, aerolysins, and cytotonic enterotoxins, which cause diarrhea, enteritis, and dysentery [4,5]. Aeromonas spp. are opportunistic bacteria commonly present in freshwater and marine environments, with Aeromonas salmonicida subsp. salmonicida, Aeromonas hydrophila, and Aeromonas veronii identified as causative agents of hemorrhagic skin ulcers and furunculosis in Nile tilapia, common carp, and channel catfish [1,6-9]. Pathogenic Aeromonas spp. kills $80-100 \%$ of commercial carp within 1-2 weeks, resulting in the deterioration of production quality in fisheries [10]. The resulting unfavorable conditions, such as hypoxia or nitrogen-waste accumulation, induce a significant reduction in immune response leading to increased risk of pathogen translocation, infection, and disease [11]. $\beta$-lactam-, aminoglycoside-, and quinolone-resistant strains of Aeromonas spp. have been isolated from water and fish worldwide [12-14]. Resistant strains have been 
isolated even from heavily polluted water; they harbor multiple resistant plasmids [15]. Aeromonas spp. can receive and deliver a set of gene-associated plasmids, integrons, and transposons [16]. These mobile elements are important for the delivery of genetic material and can specifically encode antimicrobial resistance. Aeromonas spp. resistant to several antimicrobials raises the issue of the One Health concept, which involves transmission of resistant pathogens to humans who share an aquatic source through the food chain or direct contact. Therefore, it is necessary to monitor the emergence of antimicrobial resistance in Aeromonas spp. to guide clinical treatment.

There is no effective vaccination against Aeromonas spp., because of the presence of various serotypes. Most infections caused by Aeromonas are treated using antimicrobial therapy. Another challenge in treating Aeromonas infections is the absence of Clinical and Laboratory Standards Institute (CLSI) antimicrobial breakpoints and susceptibility test protocols against Aeromonas spp., except those established for A. salmonicida [17]. Recently, the CLSI guideline (VET 04) updated the epidemiological cut-off values (ECVs) for the isolates of A. salmonicida, A. hydrophila, Flavobacterium columnare, and F. psychrophilum [18]. The ECV for $A$. salmonicida was established more than 10 years ago, and the isolates used to establish the ECV were not from fish that were part of a clinical field trial. The antimicrobial susceptibility of Aeromonas isolates have been extensively studied [19,20]; however, there are only a few studies, which determined the ECVs of Aeromonas spp. isolates from rivers and fish [21,22]. The antimicrobial susceptibilities of motile Aeromonas spp. isolates were determined by applying the florfenicol, tetracycline, and sulphonamide ECVs [23]. Therefore, it is necessary to evaluate antimicrobial-sensitivity data and ascertain the latest ECVs and resistance genes for pathogenic aquatic aeromonads sampled from the aquaculture field.

In this study, we determined the minimum inhibitory concentration (MIC) distributions, ECVs, and resistance genes for two representatives motile Aeromonas spp. (A. hydrophila and A. veronii) to demonstrate the possible hazards of excessive antimicrobial use in aquaculture, for both humans and animals.

\section{Results}

\subsection{Antimicrobial Susceptibility}

Distribution of the MICs for eight antimicrobial agents and the corresponding $\mathrm{MIC}_{50}$ and $\mathrm{MIC}_{90}$ against $A$. hydrophila and $A$. veronii were evaluated (Tables 1 and 2). The MICs obtained for Aeromonas spp. isolates ranged from $0.25-64 \mu \mathrm{g} \mathrm{mL}^{-1}$ for doxycycline, 0.03-32 $\mu \mathrm{g} \mathrm{mL}^{-1}$ for enrofloxacin, and 0.03-64 $\mu \mathrm{g} \mathrm{mL}^{-1}$ for erythromycin and florfenicol. Among the antimicrobials, oxytetracycline had the highest MICs at $>256 \mu \mathrm{g} \mathrm{mL} \mathrm{m}^{-1}$ for four A. hydrophila isolates and one $A$. veronii isolate. In $A$. hydrophila, differences between the $\mathrm{MIC}_{50}$ and $\mathrm{MIC}_{90}$ for flumequine, neomycin, and oxytetracycline were within two dilution steps; for florfenicol and enrofloxacin, five and six dilution steps, respectively. In A. veronii, differences between the $\mathrm{MIC}_{50}$ and $\mathrm{MIC}_{90}$ for gentamicin, neomycin, and oxytetracycline were within one dilution step; for florfenicol and flumequine, five and six dilution steps, respectively.

Table 1. MIC distribution of antimicrobial agents in 43 Aeromonas hydrophila isolates obtained from aquatic animals in Korea.

\begin{tabular}{|c|c|c|c|c|c|c|c|c|c|c|c|c|c|c|c|c|c|}
\hline \multirow{2}{*}{ Antimicrobials } & \multicolumn{15}{|c|}{ No. of Isolates with $\mathrm{MIC}^{\text {a }}\left(\mu \mathrm{g} \mathrm{mL}^{-1}\right)$} & \multirow{2}{*}{$\mathrm{MIC}_{50}$} & \multirow{2}{*}{$\mathrm{MIC}_{90}$} \\
\hline & 0.03 & 0.06 & 0.12 & 0.25 & 0.5 & 1 & 2 & 4 & 8 & 16 & 32 & 64 & 128 & 256 & 512 & & \\
\hline Doxycycline & & & & 8 & 3 & 5 & 4 & 6 & 9 & 3 & 2 & 2 & 1 & & & 4 & 32 \\
\hline Enrofloxacin & 7 & 0 & 1 & 4 & 8 & 8 & 2 & 1 & 0 & 1 & 6 & 5 & & & & 1 & $32<$ \\
\hline Erythromycin & 0 & 0 & 0 & 0 & 0 & 0 & 0 & 1 & 4 & 8 & 4 & 3 & 23 & & & $64<$ & $64<$ \\
\hline Florfenicol & 0 & 0 & 0 & 5 & 7 & 7 & 5 & 0 & 1 & 1 & 5 & 5 & 7 & & & 2 & $64<$ \\
\hline Flumequine & & & 7 & 0 & 1 & 2 & 2 & 0 & 2 & 5 & 7 & 6 & 7 & 4 & & 32 & 128 \\
\hline Gentamicin & & & 0 & 0 & 0 & 4 & 13 & 14 & 6 & 0 & 3 & 3 & & & & 4 & 32 \\
\hline Neomycin & & & & & 0 & 0 & 3 & 10 & 4 & 3 & 3 & 3 & 17 & & & 32 & $64<$ \\
\hline Oxytetracycline & & & & 8 & 0 & 0 & 0 & 0 & 0 & 6 & 9 & 6 & 6 & 4 & 4 & 64 & 256 \\
\hline
\end{tabular}

${ }^{a} \mathrm{MIC}$, minimum inhibitory concentration. White fields represent the range of the dilutions tested. 
Table 2. MIC distribution of antimicrobial agents in 33 Aeromonas veronii isolates obtained from aquatic animals in Korea.

\begin{tabular}{|c|c|c|c|c|c|c|c|c|c|c|c|c|c|c|c|c|c|}
\hline \multirow{2}{*}{ Antimicrobials } & \multicolumn{15}{|c|}{ No. of Isolates with $\mathrm{MIC}^{\mathrm{a}}\left(\mu \mathrm{g} \mathrm{mL^{-1 } )}\right.$} & \multirow{2}{*}{$\mathrm{MIC}_{50}$} & \multirow{2}{*}{$\mathrm{MIC}_{90}$} \\
\hline & 0.03 & 0.06 & 0.12 & 0.25 & 0.5 & 1 & 2 & 4 & 8 & 16 & 32 & 64 & 128 & 256 & 512 & & \\
\hline Doxycycline & & & & 9 & 3 & 11 & 4 & 4 & 1 & 0 & 1 & 0 & 0 & & & 1 & 4 \\
\hline Enrofloxacin & 8 & 0 & 7 & 10 & 2 & 2 & 2 & 0 & 0 & 0 & 1 & 1 & & & & 0.25 & 2 \\
\hline Erythromycin & 0 & 0 & 0 & 00 & 0 & 0 & 1 & 6 & 15 & 6 & 0 & 0 & 5 & & & 8 & $64<$ \\
\hline Florfenicol & 0 & 1 & 0 & 18 & 7 & 0 & 0 & 1 & 1 & 2 & 2 & 0 & 1 & & & 0.25 & 16 \\
\hline Flumequine & & & 8 & 2 & 11 & 3 & 1 & 0 & 0 & 2 & 4 & 2 & 0 & 0 & & 0.5 & 16 \\
\hline Gentamicin & & & 0 & 0 & 0 & 3 & 4 & 22 & 3 & 0 & 1 & 0 & & & & 4 & 8 \\
\hline Neomycin & & & & & 0 & 0 & 2 & 10 & 15 & 3 & 0 & 1 & 2 & & & 8 & 16 \\
\hline Oxytetracycline & & & & 8 & 0 & 0 & 0 & 0 & 0 & 7 & 14 & 3 & 1 & 0 & 0 & 32 & 64 \\
\hline
\end{tabular}

${ }^{a} \mathrm{MIC}$, minimum inhibitory concentration. White fields represent the range of the dilutions tested.

\subsection{ECV Establishment Using Two Analytical Methods}

We aimed to establish the ECVs for doxycycline, enrofloxacin, erythromycin, florfeni$\mathrm{col}$, flumequine, gentamicin, neomycin, and oxytetracycline by testing $43 \mathrm{~A}$. hydrophila and $33 \mathrm{~A}$. veronii isolates from various diseased aquatic animals using the normalized resistance interpretation (NRI) and ECOFFinder methods. Figure 1 shows the histogram of MICs for eight antimicrobial agents against $A$. hydrophila using the NRI method. Based on the MIC distributions, the $\mathrm{ECV}_{\mathrm{NRI}}$ for doxycycline was $2 \mu \mathrm{g} \mathrm{mL}{ }^{-1}$. This categorized $23(53.5 \%)$ isolates as non-wild type (NWT); they exhibited reduced susceptibility. The $\mathrm{ECV}_{\mathrm{NRI}}$ values for erythromycin and florfenicol were $64 \mu \mathrm{g} \mathrm{mL}^{-1}$ and $1 \mu \mathrm{g} \mathrm{mL}-1$, which categorized $23(53.5 \%)$ isolates and $24(55.8 \%)$ isolates as NWT, respectively. The $\mathrm{ECV}_{\mathrm{NRI}}$ values for enrofloxacin and flumequine were $32 \mu \mathrm{g} \mathrm{mL} \mathrm{m}^{-1}$ and $64 \mu \mathrm{g} \mathrm{mL}^{-1}$, respectively; however, the standard deviation values of $1.2 \log _{2}$ indicated inadequate precision. The NRI calculations did not generate results for oxytetracycline.

Figure 2 shows the histogram of MICs for eight antimicrobial agents and the $99.0 \%$ $\mathrm{ECV}\left(\mathrm{ECV}_{99}\right)$, which was calculated using ECOFFinder software. The $\mathrm{ECV}_{99}$ value for doxycycline was $128 \mu \mathrm{g} \mathrm{mL}^{-1}$, indicating that no isolates could be considered NWT. The $\mathrm{ECV}_{99}$ value for enrofloxacin and gentamicin was $16 \mu \mathrm{g} \mathrm{mL}^{-1}$, which categorized $11(25.6 \%)$ and six $(14.0 \%)$ isolates as NWT, respectively. However, ECOFFinder failed to provide $\mathrm{ECV}_{99}$ values for four antimicrobial agents (erythromycin, flumequine, neomycin, and oxytetracycline) revealing the lack of a normal distribution; this complicated the interpretation of the MIC distributions.

Figure 3 shows the histogram of MIC for eight antimicrobial agents against $A$. veronii us-

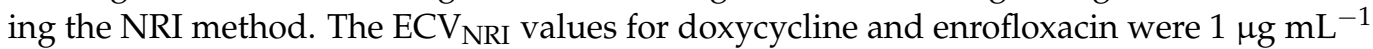
and $0.06 \mu \mathrm{g} \mathrm{mL}^{-1}$, which categorized $10(30.3 \%)$ and $25(75.8 \%)$ isolates as NWT, respectively.

Figure 4 shows the histogram of MICs for eight antimicrobial agents and the $\mathrm{ECV}_{99}$, The $\mathrm{ECV}_{99}$ values for florfenicol and flumequine were $0.5 \mu \mathrm{g} \mathrm{mL} \mathrm{L}^{-1}$ and $2 \mu \mathrm{g} \mathrm{mL}{ }^{-1}$, which categorized seven $(21.2 \%)$ and eight $(24.2 \%)$ isolates as NWT, respectively. The $\mathrm{ECV}_{99}$ values for gentamicin and neomycin were $8 \mu \mathrm{g} \mathrm{mL}^{-1}$ and $16 \mu \mathrm{g} \mathrm{m}^{-1}$, respectively. 
(A)

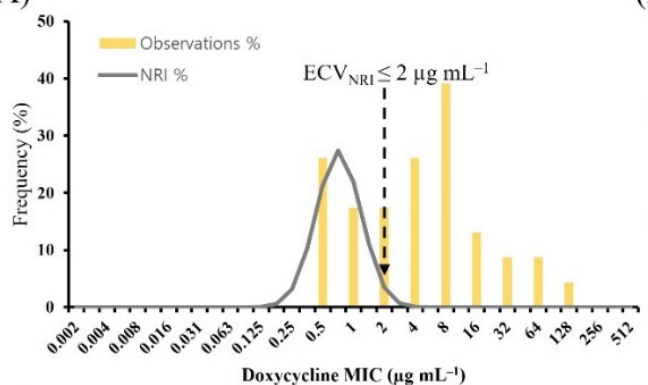

(C)

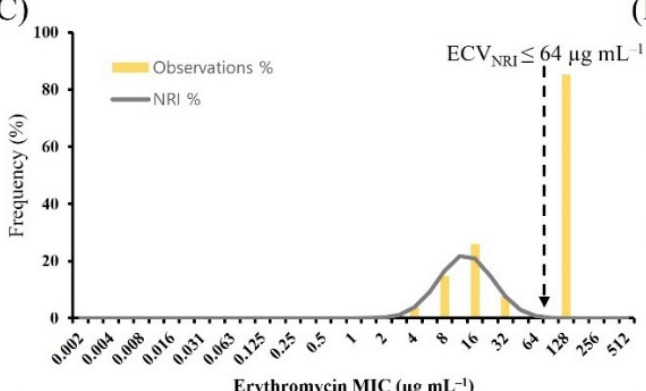

(E)

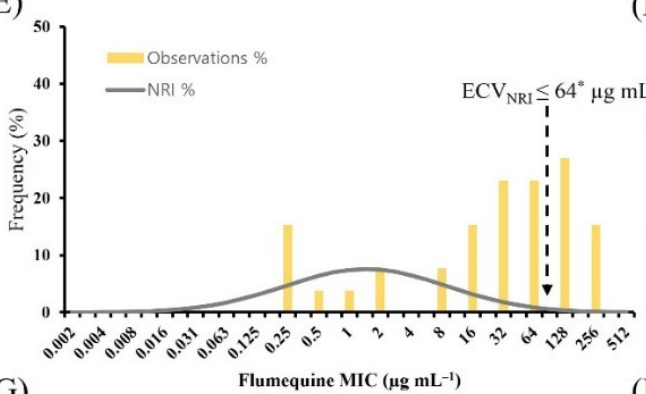

(G)

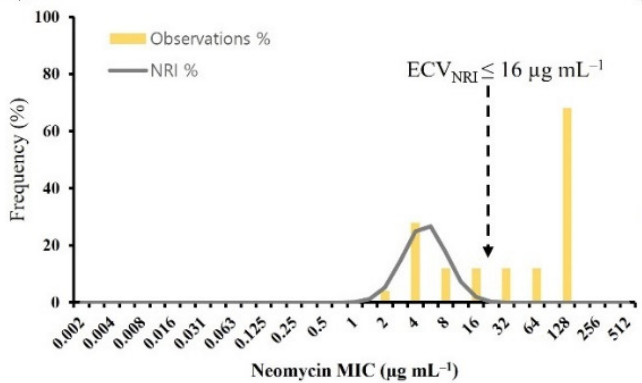

(B)

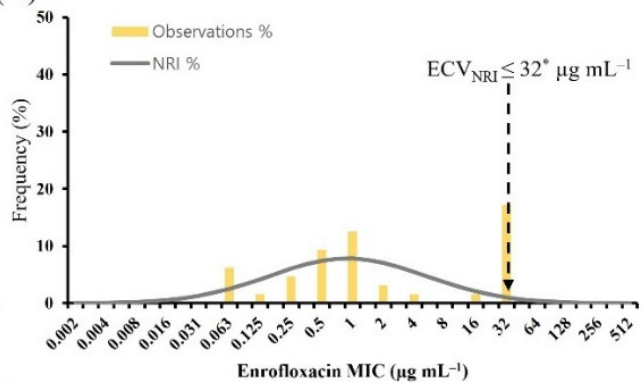

(D)

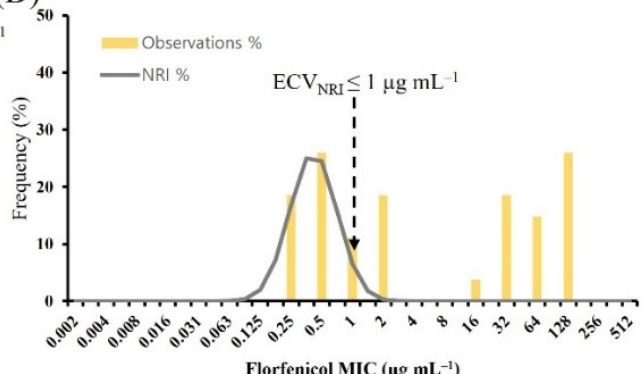

(F)

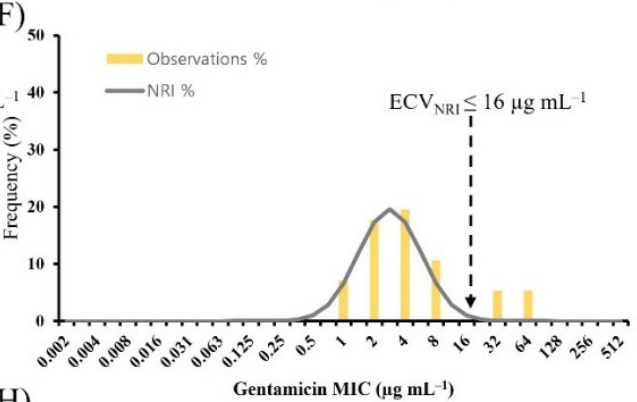

(H)

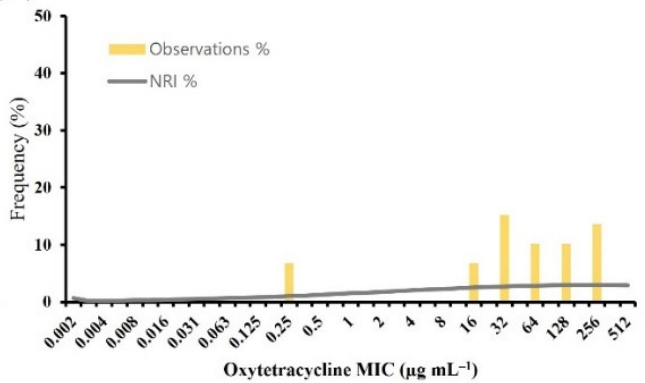

Figure 1. Distribution of MICs for Aeromonas hydrophila. MICs for A. hydrophila $(n=43)$ were determined using the broth microdilution method for (A) doxycycline, (B) enrofloxacin, (C) erythromycin, (D) florfenicol, (E) flumequine, (F) gentamicin, (G) neomycin, and (H) oxytetracycline. Gray line indicates the NRI-derived normal distribution of WT isolates. Yellow vertical lines indicate the ECVs calculated from the data. Vertical black dashed lines indicate the $\mathrm{ECV}_{\mathrm{NRI}}$ determined in this study. The standard deviations for enrofloxacin and flumequine were $>1.2 \log _{2}\left(^{*}\right)$. Oxytetracycline did not allow for $\mathrm{ECV}_{\mathrm{NRI}}$ calculation. ECV, epidemiological cut-off value; MIC, minimum inhibitory concentration; NRI, normalized resistance interpretation; WT, wild type. 
(A)

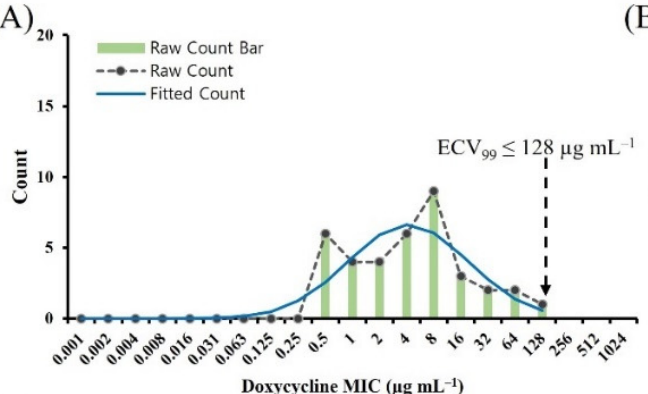

(C)

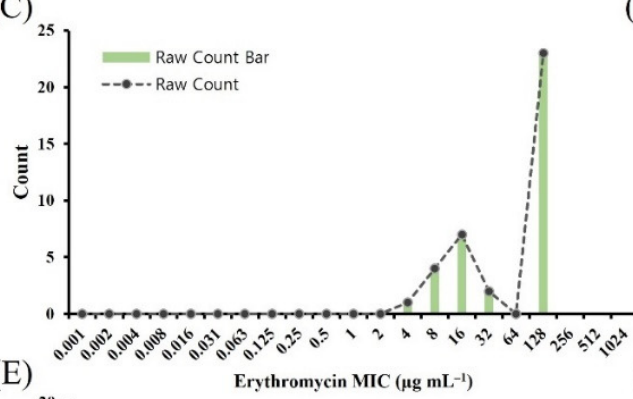

(B)

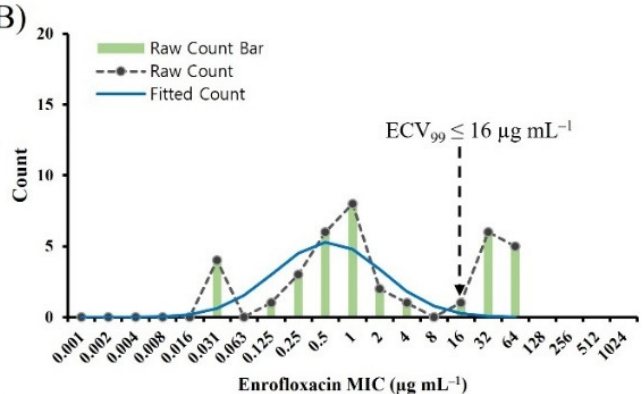

(D)

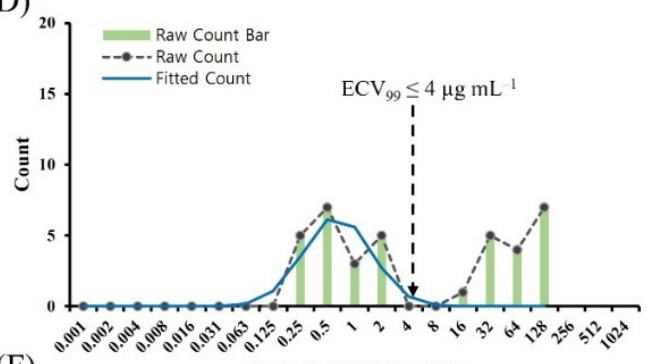

(F)

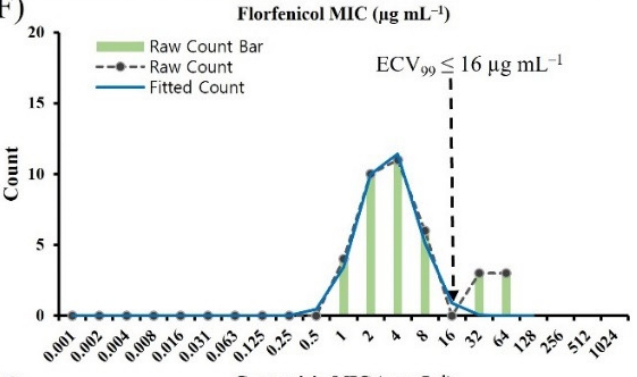

$(\mathrm{H})$

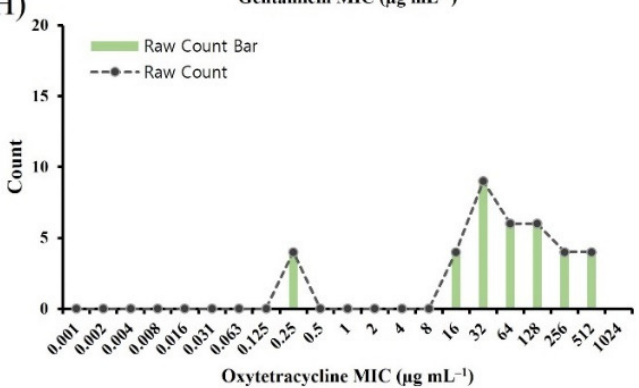

Figure 2. Distribution of MICs for Aeromonas hydrophila. MICs for A. hydrophila $(n=43)$ were determined using the broth microdilution method for (A) doxycycline, (B) enrofloxacin, (C) erythromycin, (D) florfenicol, (E) flumequine, (F) gentamicin, (G) neomycin, and (H) oxytetracycline. The blue raw-count bar and red dashed raw-count line indicate the observed number of isolates at each MIC, with the green fitted line of the MIC distribution modeled by ECOFFinder to include $99.0 \%$ of the WT isolates below the ECV. Vertical black dashed lines indicates the $\mathrm{ECV}_{99}$ determined in this study. Erythromycin, flumequine, neomycin, and oxytetracycline did not allow for $\mathrm{ECV}_{99}$ calculation. ECV, epidemiological cut-off value; MIC, minimum inhibitory concentration; WT, wild type. 
(A)

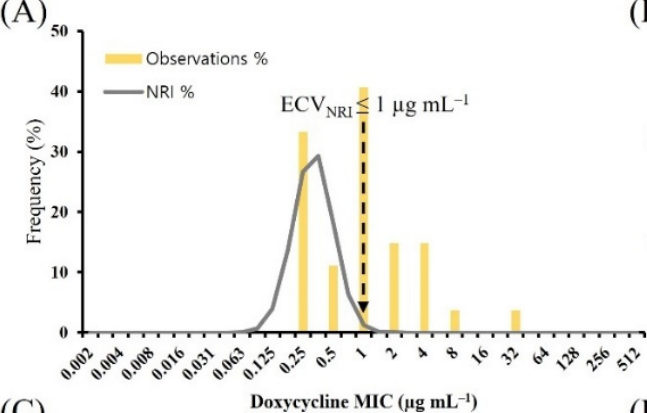

(C)

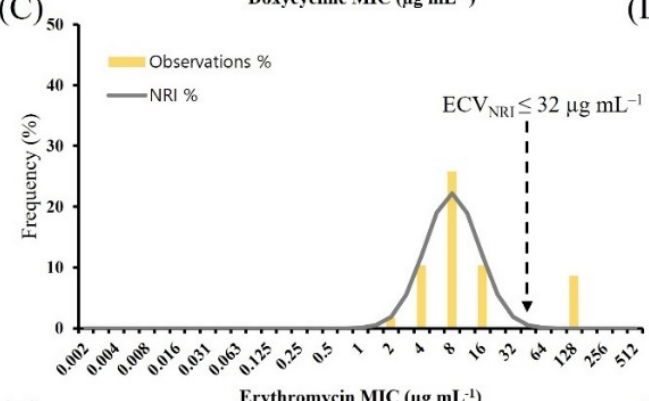

(E)

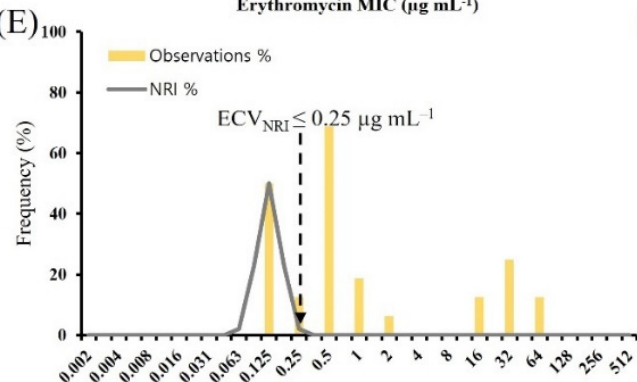

(G)

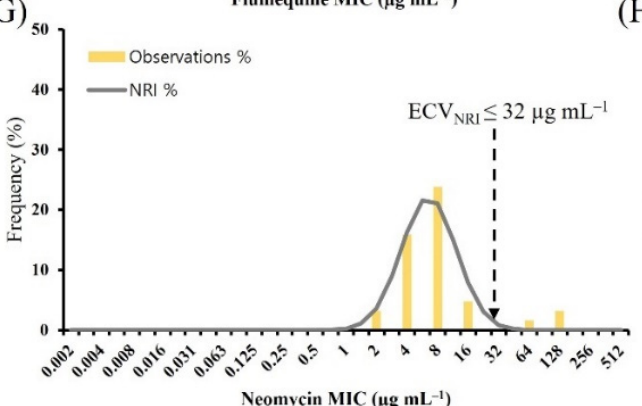

(B)

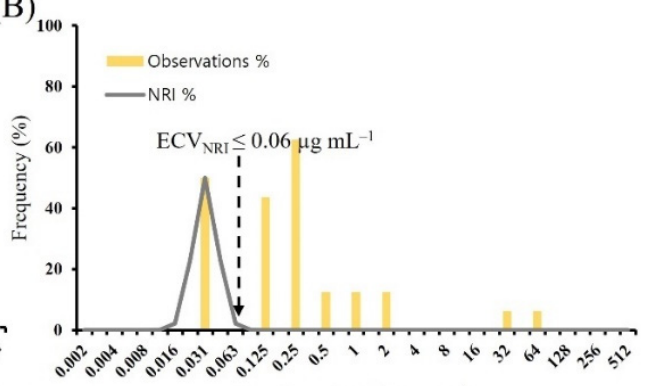

(D)

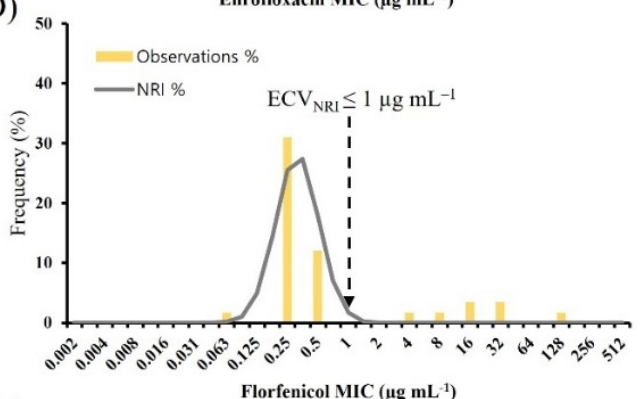

(F)

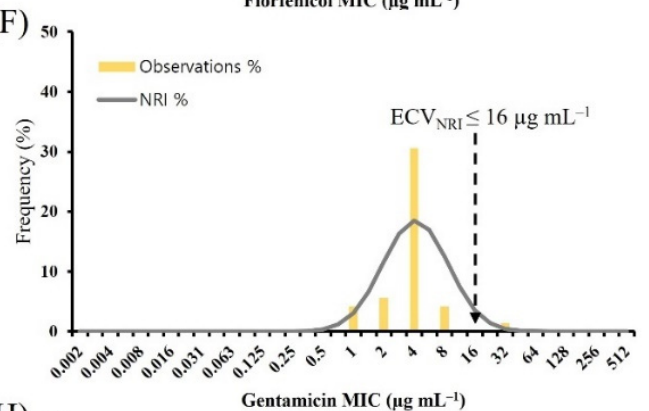

Figure 3. Distribution of MICs for Aeromonas veronii. MICs for A. veronii $(n=33)$ were determined using the broth microdilution method for (A) doxycycline, (B) enrofloxacin, (C) erythromycin, (D) florfenicol, (E) flumequine, (F) gentamicin, (G) neomycin, and (H) oxytetracycline. Gray lines indicate the NRI-derived normal distribution of WT isolates. Yellow vertical lines indicate the ECVs calculated from the data. Vertical black dashed lines indicate the $\mathrm{ECV}_{\mathrm{NRI}}$ determined in this study. The standard deviations for eight antimicrobials were below $1.2 \log _{2}$. ECV, epidemiological cut-off value; MIC, minimum inhibitory concentration; NRI, normalized resistance interpretation; WT, wild type. 
(A)

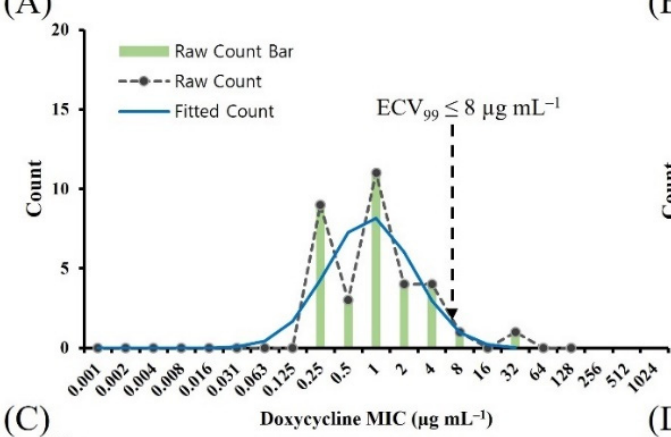

(B)

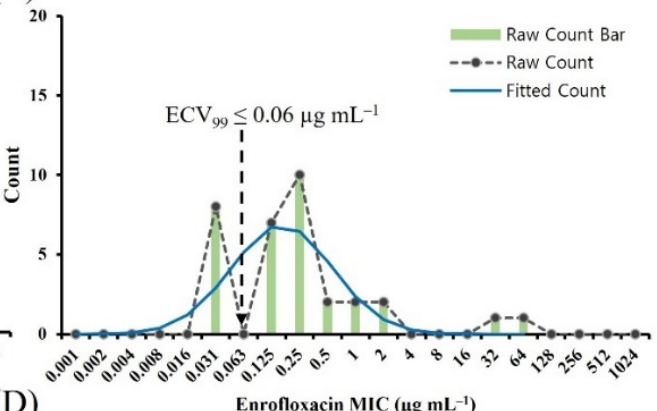

(D)

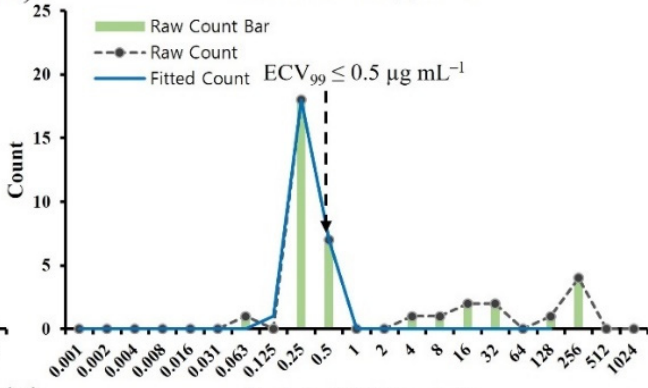

(F)

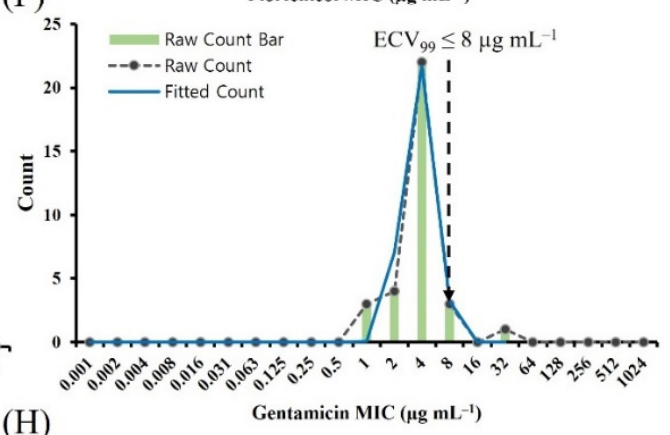

(H)

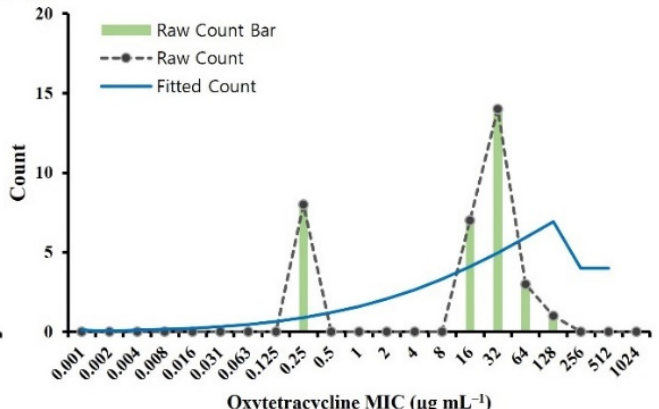

Figure 4. Distribution of MICs for Aeromonas veronii. MICs for A. veronii $(n=33)$ were determined using the broth microdilution method for (A) doxycycline, (B) enrofloxacin, (C) erythromycin, (D) florfenicol, (E) flumequine, (F) gentamicin, (G) neomycin, and (H) oxytetracycline. The blue raw-count bar and red dashed raw-count line depict the observed number of isolates at each MIC, with the green fitted line of the MIC distribution modeled by ECOFFinder to include $99.0 \%$ of the WT isolates below the ECV. Vertical black dashed lines indicate the $\mathrm{ECV}_{99}$ determined in this study. Oxytetracycline did not allow for $\mathrm{ECV}_{99}$ calculation. $\mathrm{ECV}$, epidemiological cut-off value; $\mathrm{MIC}$, minimum inhibitory concentration; WT, wild type.

\subsection{Comparison of the $E C V_{C L S I}, E C V_{N R I}$, and $E C V_{99}$}

We compared the ECVs of eight antimicrobial agents for A. hydrophila and A. veronii isolates using the CLSI, NRI, and ECOFFinder methods. There is no breakpoint for the two Aeromonas spp. isolates; however, recently, the CLSI provided six ECVs for A. hydrophila [18]. The ECV $\mathrm{CLSI}_{\text {and }} \mathrm{ECV}_{\mathrm{NRI}}$ for erythromycin against $A$. hydrophila, was $64 \mu \mathrm{g} \mathrm{mL}{ }^{-1}$ (Table 3). 
Additionally, the $\mathrm{ECV}_{\mathrm{NRI}}$ and $\mathrm{ECV}_{99}$ for gentamicin was $16 \mu \mathrm{g} \mathrm{mL}^{-1}$, which was two-fold higher than $\mathrm{ECV}_{\mathrm{CLSI}}$. The $\mathrm{ECV}_{99}$ for enrofloxacin was $16 \mu \mathrm{g} \mathrm{mL}^{-1}$, which was more than

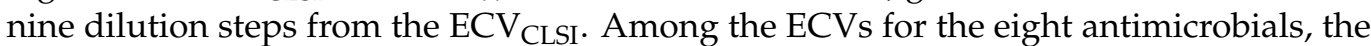
ECV for florfenicol was optimal, showing the least 1-fold dilution between ECV $_{C L S I}$ and $\mathrm{ECV}_{\mathrm{NRI}}$ or $\mathrm{ECV}_{99}$. We calculated values for flumequine and neomycin using only the NRI method. The CLSI has not provided the breakpoint or ECVs for A. veronii. The ECV $\mathrm{NRI}_{\text {and }}$ $\mathrm{ECV}_{99}$ values for enrofloxacin $\left(0.06 \mu \mathrm{g} \mathrm{mL}^{-1}\right)$ and erythromycin $\left(32 \mu \mathrm{g} \mathrm{mL}^{-1}\right)$ were the

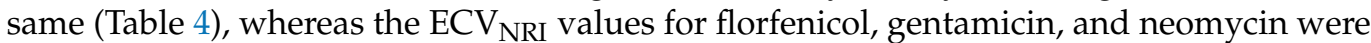
one-fold higher than the $\mathrm{ECV}_{99}$ values. Oxytetracycline was evaluated using only the NRI method with $0.5 \mu \mathrm{g} \mathrm{mL}^{-1}$ as the $\mathrm{ECV}_{\mathrm{NRI}}$ value.

Table 3. Comparison of the ECVs of eight antimicrobial agents for Aeromonas hydrophila isolates based on the CLSI, NRI, and ECOFFinder methods.

\begin{tabular}{|c|c|c|c|c|c|c|c|c|c|c|}
\hline Species & Antimicrobial & $\begin{array}{c}\mathrm{ECV}_{\mathrm{CLSI}} \\
\left(\mu \mathrm{g} \mathrm{mL}^{-1}\right)\end{array}$ & WT(\%) & NWT(\%) & $\begin{array}{c}\mathrm{ECV}_{\mathrm{NRI}} \\
\left(\mu \mathrm{g} \mathrm{mL}^{-1}\right)\end{array}$ & $\mathrm{WT}(\%)$ & NWT(\%) & $\begin{array}{c}\mathrm{ECV}_{99} \\
\left(\mu \mathrm{g} \mathrm{mL}^{-1}\right)\end{array}$ & WT(\%) & NWT(\%) \\
\hline \multirow{8}{*}{$\begin{array}{c}\text { A. } \\
\text { hydrophila }\end{array}$} & Doxycycline & ND & - & - & 2 & 46.5 & 53.5 & 128 & 100.0 & 0.0 \\
\hline & Enrofloxacin & 0.03 & 16.3 & 83.7 & $32^{\#}$ & 88.4 & 11.6 & 16 & 74.4 & 25.6 \\
\hline & Erythromycin & 64 & 46.5 & 53.5 & 64 & 46.5 & 53.5 & ND & - & - \\
\hline & Florfenicol & 2 & 55.8 & 44.2 & 1 & 44.2 & 55.8 & 4 & 55.8 & 44.2 \\
\hline & Flumequine & ND & - & - & $64^{\#}$ & 74.4 & 25.6 & ND & - & - \\
\hline & Gentamicin & 4 & 72.1 & 27.9 & 16 & 86.0 & 14.0 & 16 & 86.0 & 14.0 \\
\hline & Neomycin & ND & - & - & 16 & 46.5 & 53.5 & ND & - & - \\
\hline & Oxytetracycline & 0.25 & 18.6 & 62.8 & ND & - & - & ND & - & - \\
\hline
\end{tabular}

\# Standard deviation $>1.2 \log _{2}$. CLSI, Clinical and Laboratory Standards Institute; ECV, epidemiological cut-off value; ND, not possible to determine the ECV; NWT, non-wild type; WT, wild type.

Table 4. Comparison of the ECVs of eight antimicrobial agents for Aeromonas veronii isolates based on the CLSI, NRI, and ECOFFinder methods.

\begin{tabular}{|c|c|c|c|c|c|c|c|c|c|c|}
\hline Species & Antimicrobial & $\begin{array}{c}\mathrm{ECV}_{\mathrm{CLSI}} \\
\left(\mu \mathrm{g} \mathrm{mL}^{-1}\right)\end{array}$ & WT(\%) & NWT(\%) & $\begin{array}{c}\mathrm{ECV}_{\mathrm{NRI}} \\
\left(\mu \mathrm{g} \mathrm{mL^{-1 }}\right)\end{array}$ & WT(\%) & NWT(\%) & $\begin{array}{c}\mathrm{ECV}_{99} \\
\left(\mu \mathrm{g} \mathrm{mL}^{-1}\right)\end{array}$ & WT(\%) & NWT(\%) \\
\hline \multirow{8}{*}{ A. veronii } & Doxycycline & ND & - & - & 1 & 69.7 & 30.3 & 8 & 97.0 & 3.0 \\
\hline & Enrofloxacin & $\mathrm{ND}$ & - & - & 0.06 & 24.2 & 75.8 & 0.06 & 24.2 & 75.8 \\
\hline & Erythromycin & $\mathrm{ND}$ & - & - & 32 & 84.8 & 15.2 & 32 & 84.8 & 15.2 \\
\hline & Florfenicol & ND & - & - & 1 & 78.8 & 21.2 & 0.5 & 78.8 & 21.2 \\
\hline & Flumequine & $\mathrm{ND}$ & - & - & 0.25 & 30.3 & 69.7 & 2 & 75.8 & 24.2 \\
\hline & Gentamicin & $\mathrm{ND}$ & - & - & 16 & 97.0 & 3.0 & 8 & 97.0 & 3.0 \\
\hline & Neomycin & ND & - & - & 32 & 90.9 & 9.1 & 16 & 90.9 & 9.1 \\
\hline & Oxytetracycline & $\mathrm{ND}$ & - & - & 0.5 & 24.2 & 75.8 & $\mathrm{ND}$ & - & - \\
\hline
\end{tabular}

CLSI, Clinical and Laboratory Standards Institute; ECV, epidemiological cut-off value; ND, not possible to determine the ECV; NWT, non-wild type; WT, wild type.

\subsection{Presumptive Multidrug-Resistant ( $p M D R$ ) Aeromonas spp. Isolates}

A total of $18.6 \%(n=8)$ of the isolates presented a pMDR phenotype, suggesting that multiple antimicrobial resistance is a common phenomenon in A. hydrophila (Table 5). All isolates from Anguilla japonica, Silurus asotus, Salmo salar, and Misgurnus mizolepis were resistant to three or more classes of antimicrobials. One isolate was resistant to seven antimicrobial agents, and five isolates were resistant to six agents. Additionally, 24.2\% $(n=8)$ of $A$. veronii isolates presented the pMDR phenotype, and were highly resistant to enrofloxacin, florfenicol, and oxytetracycline. None of the isolates were resistant to all the eight antimicrobial agents. 
Table 5. pMDR profiles of Aeromonas hydrophila and Aeromonas veronii isolates collected from aquatic animals.

\begin{tabular}{ccccc}
\hline Strain & Isolate No. & Host & Year & Phenotype \\
\hline 20FBAer0358 & Anguilla japonica & 2020 & E, Er, F, Fl, G, N, O \\
& 20FBAer0371 & Anguilla japonica & 2020 & Er, F, Fl, G, N, O \\
& 20FBAer0351 & Anguilla japonica & 2020 & E, F, G, O \\
A. hydrophila & 19FBAHy0001 & Silurus asotus & 2019 & E, Er, F, Fl, N, O \\
& 18FBAHy0001 & Silurus asotus & 2018 & E, Er, F, Fl, N, O \\
& 18FBAhy0003 & Anguilla japonica & 2018 & E, Er, F, Fl, N, O \\
& 17FBAHy0013 & Salmo salar & 2017 & E, Er, F, Fl, N, O \\
& 17FBAHy0006 & Misgurnus mizolepis & 2017 & F, G, N, O \\
\hline 20FBAer0306 & Anguilla japonica & 2020 & E, F, G, N, O \\
& 20FBAer0374 & Oncorhynchus mykiss & 2020 & E, Er, N, O \\
& 21FBAer0172 & Cyprinus carpio nudus & 2018 & E, Er, F, Fl, N, O \\
21FBAer0163 veronii & Cyprinus carpio nudus & 2018 & E, F, Fl, O \\
& 21FBAer0164 & Carassius carassius & 2018 & E, F, Fl, O \\
& 21FBAer0171 & Cyprinus carpio nudus & 2018 & E, F, O \\
& FP3978 & Cyprinus carpio nudus & 2010 & D, E, Er, Fl, O \\
& FP3973 & Cyprinus carpio nudus & 2010 & E, F, O \\
\hline
\end{tabular}

$\mathrm{D}$, doxycycline; E, enrofloxacin; Er, erythromycin; F, florfenicol; Fl, flumequine; $\mathrm{G}$, gentamicin; $\mathrm{N}$, neomycin; $\mathrm{O}$ oxytetracycline; pMDR, presumptive multidrug-resistant.

\subsection{Distribution of Antimicrobial Resistance Genes (ARGs)}

We analyzed four tet genes (tet $A$, tet $B$, tet $D$, and tet $E)$ encoding proteins involved in tetracycline efflux (Figure 5). In A. hydrophila, all the tet-positive isolates (35 isolates) were

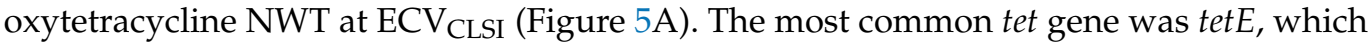
was found in $14(40 \%)$ NWT isolates, followed by tetA, which was found in $12(34.3 \%)$ NWT isolates. Some of the isolates carried more than one tet gene, with tet $A$-tet $D$ (three isolates) and tetA-tetE (five isolates) related to the oxytetracycline MICs ranging from $32 \mu \mathrm{g} \mathrm{mL} \mathrm{L}^{-1}$ to $256 \mu \mathrm{g} \mathrm{mL} \mathrm{m}^{-1}$ and demonstrating high resistance to oxytetracycline. The tet $B$ gene was not detected in any of the strains. We analyzed the four tet genes in A. veronii (Figure 6). In $A$. veronii, all the tet-positive isolates ( 25 isolates) were oxytetracycline NWT at $\mathrm{ECV}_{\mathrm{NRI}}$ (Figure 6A), and the most common tet gene was tetE, which was found in $13(52 \%)$ of the NWT isolates. Additionally, A. veronii isolates with MICs of $64 \mu \mathrm{g} \mathrm{mL}^{-1}$ (two strains) and $128 \mu \mathrm{g} \mathrm{mL}^{-1}$ (one strain) carried two tet genes, (tet $A$-tetE and tetD-tetE, respectively). The tet $B$ gene was not detected in any of the strains.

Florfenicol NWT in A. hydrophila and A. veronii isolates was examined to determine the presence of the resistance genes for chloramphenicol acetyltransferase (cat) and florfenicol resistance (floR). In A. hydrophila, 79.2\% (19/24) of the ARG-positive isolates were florfenicol NWT at $\mathrm{ECV}_{99}$ (Figure 5B), with cat and floR detected in $0 \%(0 / 19)$ and $73.7 \%(14 / 19)$ of the NWT isolates, respectively. Moreover, five isolates with MICs of $32 \mu \mathrm{g} \mathrm{mL} L^{-1}$ and $64 \mu \mathrm{g} \mathrm{mL}^{-1}$ carried both the resistance genes (cat-floR). We detected no resistance genes in 19 isolates among all the strains. In A. veronii, $24.0 \%(6 / 25)$ of the florfenicol NWT at $\mathrm{ECV}_{99}$ were ARG-positive isolates (Figure 6B); however, 73.1\% (19/26) of florfenicol WT carried the cat gene. Furthermore, six A. veronii isolates with MICs ranging from $8 \mu \mathrm{g} \mathrm{mL}^{-1}$ to $32 \mu \mathrm{g} \mathrm{mL}^{-1}$ and $>64 \mu \mathrm{g} \mathrm{mL}-1$ carried two resistant genes (cat-floR).

We tested $A$. hydrophila and $A$. veronii enrofloxacin NWT isolates for the three resistance genes, $q n r A$, $q n r B$, and $q n r S$. In A. hydrophila, $77.8 \%(7 / 9)$ of the ARG-positive isolates were enrofloxacin NWT at $\mathrm{ECV}_{99}$ (Figure 5C), with qnrS detected in 54.5\% $(6 / 11)$ of the NWT isolates; only one at MIC $>32 \mu \mathrm{g} \mathrm{mL}^{-1}$ harbored more than one type of $q n r$ gene. In A. veronii, $88.9 \%(8 / 9)$ of the ARG-positive isolates were enrofloxacin NWT at $\mathrm{ECV}_{99}$ (Figure 6C), with $q n r B$ and $q n r S$ detected in $8 \%(2 / 25)$ and $24 \%(6 / 25)$ of the NWT isolates, respectively. Furthermore, we did not detect the qnrA gene in any of the A. hydrophila or $A$. veronii strains. 
(A)

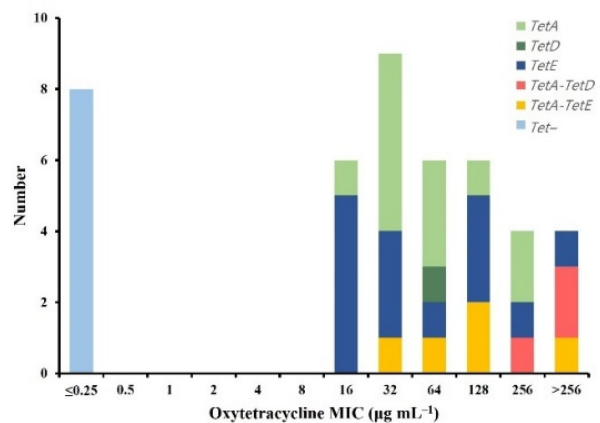

(C)

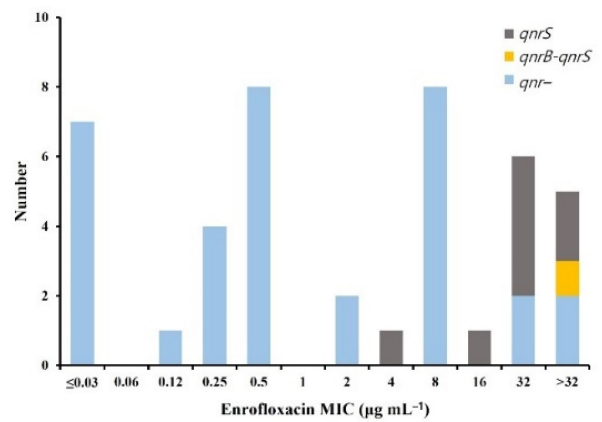

(B)

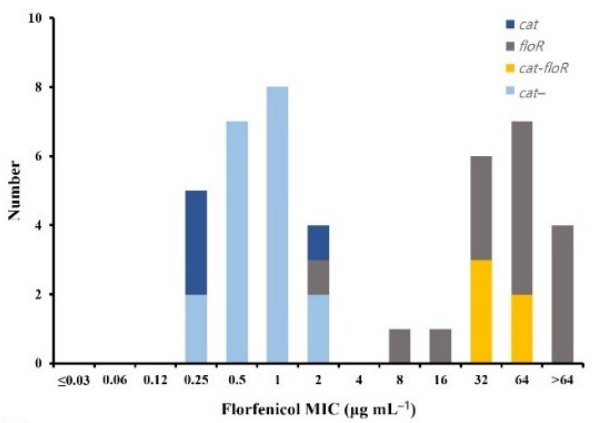

(D)

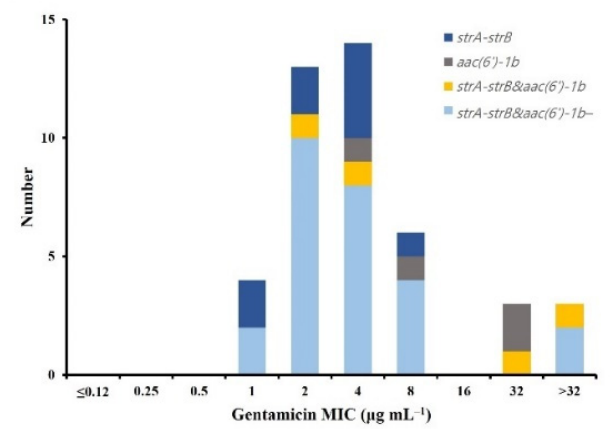

Figure 5. Distribution of ARGs among 43 Aeromonas hydrophila isolates. (A) Tetracycline-resistant genes (tet $A$, tet $B$, tet $D$, and tet $E),(\mathbf{B})$ florfenicol-resistant genes (cat and floR), (C) quinolone-resistant genes ( $q n r A, q n r B$, and $q n r S)$, and (D) aminoglycoside-resistant genes ( $\operatorname{str} A$-strB and $\left.a a c\left(6^{\prime}\right)-1 b\right)$. ARG, antimicrobial resistance gene.

(A)

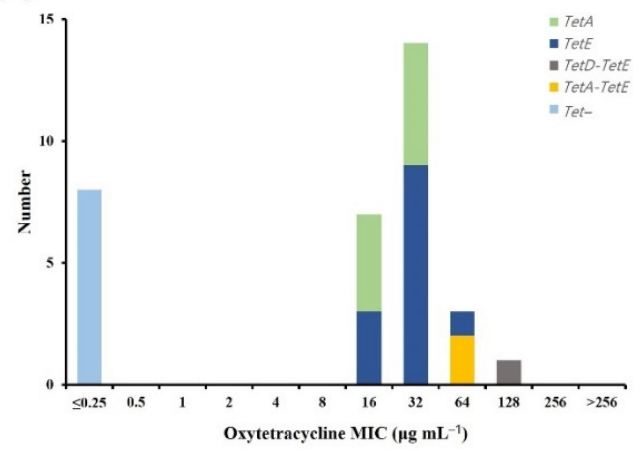

(C)

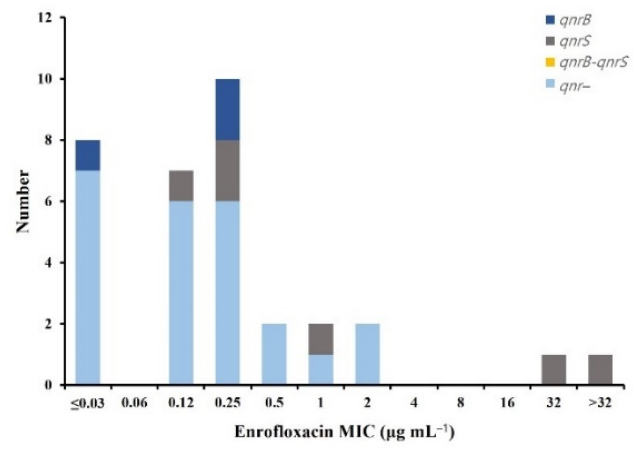

(B)

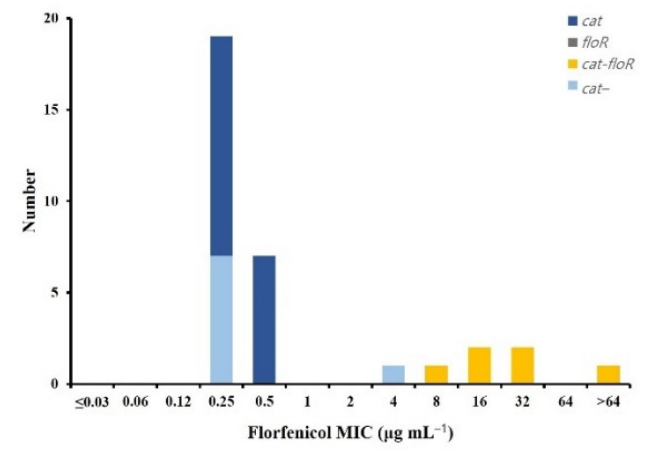

(D)

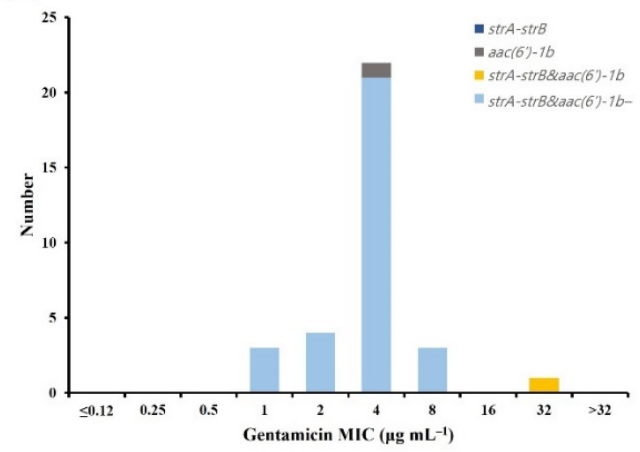

Figure 6. Distribution of ARGs among 33 Aeromonas veronii isolates. (A) Tetracycline-resistant genes (tet $A$, tet $B$, tet $D$, and tet $E),(B)$ florfenicol-resistant genes (cat and floR), (C) quinolone-resistant genes $(q n r A, q n r B$, and $q n r S)$, and (D) aminoglycoside-resistant genes (strA-strB and $\left.a a c\left(6^{\prime}\right)-1 b\right)$. ARG, antimicrobial resistance gene. 
We tested $A$. hydrophila and $A$. veronii gentamicin NWT isolates for the two resistance genes $\operatorname{str} A$-strB and $a a c\left(6^{\prime}\right)-1 b$. In $A$. hydrophila, 23.5\% (4/17) of the ARG-positive isolates were gentamicin NWT at $\mathrm{ECV}_{99}$ (Figure 5D); however, $24.3 \%$ of the gentamicin WT 37 isolates carried the $s t r A$-strB gene. Among the NWT isolates, $66.7 \%$ harbored more than one resistance gene [e.g., $\operatorname{str} A-\operatorname{str} B-a a c\left(6^{\prime}\right)-1 b$ ]. In $A$. veronii, there were no ARGs in the 31 isolates from the different strains (Figure 6D); however, one isolate with an MIC of $32 \mu \mathrm{g} \mathrm{mL}{ }^{-1}$ harbored two resistant genes [str $\left.A-\operatorname{str} B-a a c\left(6^{\prime}\right)-1 b\right]$. Table 6 summarizes the ARG distributions in the $A$. hydrophila and $A$. veronii isolates.

Table 6. ARG distribution in Aeromonas hydrophila and Aeromonas veronii.

\begin{tabular}{|c|c|c|c|c|c|c|c|c|c|c|c|c|c|c|c|}
\hline & \multicolumn{5}{|c|}{ Tetracycline } & \multicolumn{3}{|c|}{ Florfenicol } & \multicolumn{4}{|c|}{ Quinolone } & \multicolumn{3}{|c|}{ Aminoglycoside } \\
\hline & tet $A$ & tetB & tetD & tetE & $\underset{*}{\text { Others }}$ & cat & floR & $\underset{*}{\text { Others }}$ & $q n r A$ & $q n r B$ & $q n r S$ & $\underset{*}{\text { Others }}$ & $\begin{array}{l}\text { strA- } \\
\text { strB }\end{array}$ & $\begin{array}{c}a a c\left(6^{\prime}\right)- \\
1 b\end{array}$ & $\underset{*}{\text { Others }}$ \\
\hline $\begin{array}{l}\text { A. hy- } \\
\text { drophila }\end{array}$ & 12 & - & 1 & 14 & 8 & 4 & 15 & 5 & - & - & 8 & 1 & 9 & 4 & 4 \\
\hline $\begin{array}{c}A . \\
\text { veronii }\end{array}$ & 9 & - & 0 & 13 & 3 & 19 & - & 6 & - & 3 & 6 & - & - & 1 & 1 \\
\hline
\end{tabular}

\subsection{Quality Control (QC)}

Eight antimicrobial agents of QC MICs for Escherichia coli ATCC 25922, Aeromonas salmonicida subsp. salmonicida ATCC 33658, and Enterococcus faecalis ATCC 29212 were within the acceptable range (94.3 to $100 \%)$ for the standard broth-microdilution method, as stipulated by the CLSI documents, M45, M7, and VET04 [18,24,25]. The results for doxycycline and neomycin against $A$. salmonicida ATCC 33658 were excluded from the QC, because of the lack of an established acceptable range in CLSI document VET04. Table S1 shows the MICs for the QC strains.

\section{Discussion}

The development of multiple antibiotic resistance strains of $A$. hydrophila and A. veronii in recent years is a serious public health concern, because of the possibility of their transmission from infected fish or water sources to humans and the subsequent infections [26]. In this study, we established eight ECVs for $43 \mathrm{~A}$. hydrophila and $33 \mathrm{~A}$. veronii isolates from

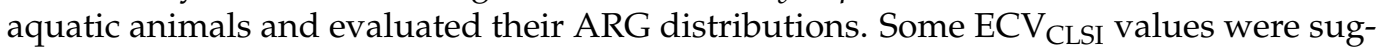
gested for A. hydrophila [18]. The lack of clinical breakpoints or guidelines to interpret ECVs for $A$. veronii prompted the use of two methods for determining ECVs and interpreting the antimicrobial susceptibility of $A$. hydrophila and $A$. veronii.

Three antimicrobials (doxycycline, enrofloxacin, and oxytetracycline) exhibited bimodal MIC distributions, which revealed two clearly distinct populations of $A$. hydrophila and $A$. veronii. Based on these distributions, the calculated $\mathrm{MIC}_{50}\left(4 \mu \mathrm{g} \mathrm{mL}^{-1}\right)$ for gentamicin against $A$. hydrophila and $A$. veronii was higher than $1 \mu \mathrm{g} \mathrm{mL} \mathrm{m}^{-1}$. This is in line with that reported for 138 Aeromonas spp. isolates recovered from European rivers [27]. The $\mathrm{MIC}_{50}$ and $\mathrm{MIC}_{90}$ values for oxytetracycline were $34.97 \mu \mathrm{g} \mathrm{mL}^{-1}$ and $149.26 \mu \mathrm{g} \mathrm{mL}^{-1}$, respectively, for 64 pathogenic Aeromonas strains isolated from ornamental fish [28]. Similarly, the $\mathrm{MIC}_{50}$ values were $\leq 2 \mu \mathrm{g} \mathrm{mL}^{-1}$ for florfenicol, $8 \mu \mathrm{g} \mathrm{mL}^{-1}$ for oxytetracycline, and $0.5 \mu \mathrm{g} \mathrm{mL}^{-1}$ for ciprofloxacin for 72 aeromonads isolated from koi carp [29]. These findings suggested that the isolates obtained 10 years ago were more susceptible to these drugs.

Tetracycline classes, including oxytetracycline and doxycycline, are broad-spectrum agents extensively used to treat bacterial infections and prevent infections in aquaculture. However, oxytetracycline is poorly absorbed in the fish gut; therefore, it must be administered at high doses [30]. This study showed that $89.2 \%$ of $A$. hydrophila could be categorized as NWT upon applying an oxytetracycline $\mathrm{ECV}_{\mathrm{CLSI}}$ of $0.25 \mu \mathrm{g} \mathrm{mL}^{-1} ; 75.8 \%$ of $A$. veronii were determined as NWT upon applying an oxytetracycline $\mathrm{ECV}_{\mathrm{NRI}}$ of $0.5 \mu \mathrm{g} \mathrm{mL} \mathrm{m}^{-1}$. This confirmed the high resistance rate in Aeromonas spp. However, 33 Aeromonas isolates (14.2\%) recovered from 16 rivers were considered NWT for tetracycline (23), and 39 Aeromonas 
isolates $(40.6 \%)$ from different fish species with reduced susceptibility to tetracycline were classified as NWT [23]. Additionally, A. hydrophila isolates from tilapia, carp, and channel catfish were more susceptible to doxycycline than to oxytetracycline [31]. Aeromonas spp. easily develop single or multiple antibiotic resistance phenotypes and are generally resistant to tetracyclines, quinolones, and $\beta$-lactams [5,32]. Moreover, tetracycline-resistant Aeromonas isolates are observed in wastewater discharge, lakes, and carp ponds [32-35]. In this study, we found that $62.8 \%$ of $A$. hydrophila isolates and $75.8 \%$ of $A$. veronii NWT isolates harbored tet $A$, tet $D$, tet $E$, or more than one tet gene, indicating that the WT isolates did not possess any tet genes. Aeromonas spp. isolates predominantly carried tet $E$, followed by tet $A$. However, $37 \%$ of $A$. veronii isolates recovered from channel catfish carried tet $E$, and $3.8 \%$ of isolates carried tet $A$ [36]. Furthermore, $A$. hydrophila isolates showing oxytetracycline MICs ranging from 32-256 $\mu \mathrm{g} \mathrm{mL}^{-1}$ harbored more than one tet gene (tetA-tetE and tet $A$-tetD), indicating that the degree of oxytetracycline resistance was associated with the number and type of tet genes present. E. coli isolates harboring tet $A$ and tet $B$ or $\operatorname{tet} A$ and tetC exhibited high MICs for tetracycline $\left(256 \mu \mathrm{g} \mathrm{mL}^{-1}\right)$ or oxytetracycline $\left(512 \mu \mathrm{g} \mathrm{mL}^{-1}\right)$ [37]. The $\mathrm{ECV}_{\mathrm{CLSI}}$ for $A$. hydrophila and $\mathrm{ECV}_{\mathrm{NRI}}$ for $A$. veronii might account for the correlations between the NWT isolates and the distribution of resistance genes.

In Korea, florfenicol is approved for use against bacterial diseases in Oncorhynchus mykiss, A. japonica, and Seriola quinqueradiata [38]. The $\mathrm{ECV}_{\mathrm{NRI}}$ for florfenicol is $1 \mu \mathrm{g} \mathrm{mL} \mathrm{m}^{-1}$ for $A$. hydrophila (55.8\%) and A. veronii (21.2\%), which were categorized as NWT with reduced susceptibility. However, $2.1 \%$ isolates of Aeromonas spp. are NWT considering the $\mathrm{ECV}_{\mathrm{NRI}}\left(2 \mu \mathrm{g} \mathrm{mL}{ }^{-1}\right)[21]$, and $25.5 \%$ are NWT considering the $\mathrm{ECV}_{\mathrm{NRI}}\left(4 \mu \mathrm{g} \mathrm{mL}{ }^{-1}\right)$ [23]. The high frequency of NWT isolates from Korea could be associated with the excessive use of antimicrobial agents in aquaculture; the recorded florfenicol sales was approximately six tons in 2019 [39]. Additionally, we detected cat and floR in A. hydrophila and A. veronii NWT isolates; both genes are associated with high MICs. A total of $7.5 \% A$. veronii isolates harbored floR, which conferred resistance to florfenicol [36]. A resistance cassette, carrying the floR gene in $A$. salmonicida enables mobilization [40]. The first floR-containing plasmid was discovered in Aeromonas bestiarum [41]. Interestingly, the presence of cat was related to a low MIC for florfenicol $\left(0.25\right.$ or $\left.0.5 \mu \mathrm{g} \mathrm{mL} \mathrm{m}^{-1}\right)$. These results indicated a higher correlation between the presence of floR and NWT categorization, compared to that with the presence of cat.

Enrofloxacin is a member of the fluoroquinolone family of antibiotics and exhibits strong bactericidal activity against aerobic and facultative anaerobic bacteria [42]. For A. hydrophila, the $\mathrm{ECV}_{\mathrm{CLSI}}$ of $0.03 \mu \mathrm{g} \mathrm{mL}^{-1}$ was lower than the $\mathrm{ECV}_{99}$ of $16 \mu \mathrm{g} \mathrm{mL}^{-1}$, indicating that lowering the ECV would increase the likelihood of identifying resistance genes or mutants while increasing the risk of misclassifying the number of WT isolates. Based on our findings, an ECV CLSI of $0.03 \mu \mathrm{g} \mathrm{mL}^{-1}$ would misclassify $58.1 \%$ of NWT (25 isolates), compared to an $\mathrm{ECV}_{99}$ of $16 \mu \mathrm{g} \mathrm{mL} \mathrm{m}^{-1}$. We mostly detected qnrS in A. hydrophila and $A$. veronii NWT isolates; therefore, ECVs should be established in detail based on the ARG distributions. qnrS was the most prevalent, with its presence in $68 \%$ of aeromonad isolates that demonstrated high levels of resistance to nalidixic acid and ciprofloxacin; no amplicon was detected for $q n r A$ [43]. The detection of the factors enabling plasmidmediated quinolone resistance indicated that the complex Aeromonas mobilome increases the possibility of horizontal gene transfer, including that of $q n r S$ and $q n r B$.

Erythromycin is not approved for use in the USA; however, Aeromonas strains highly resistant to erythromycin have been isolated from foreign countries [44]. Additionally, Aeromonas spp. are resistant to penicillin, cephalosporins, vancomycin, and erythromycin $[45,46]$. In this study, $53.5 \%$ and $15.2 \%$ of $A$. hydrophila and $A$. veronii, respectively, were categorized as

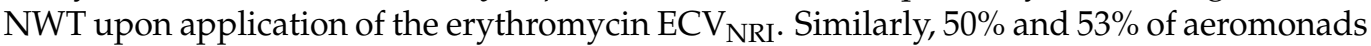
isolated from lakes and chickens, respectively, showed resistance to erythromycin $[47,48]$. Furthermore, harboring macrolide $M a c B A B C$ transporter genes confers erythromycin resistance; the $M a c A$ gene regulates the drug-binding and ATPase activity of $M a c B$ [49]. We did not investigate the distribution of macrolide resistance genes; further studies are required 
to elucidate the cause underlying the acquisition of erythromycin resistance, owing to the high prevalence of erythromycin NWT Aeromonas spp. isolates.

The results showed that $3 \%$ of $A$. veronii was classified as NWT upon application of the gentamicin $\mathrm{ECV}_{\mathrm{NRI}}$ and $\mathrm{ECV}_{99}$. Consistent with these findings, $2 \%$ of Aeromonas spp. exhibited gentamicin resistance; however, no $A$. veronii isolate was resistant to gentamicin [50]. We did not detect any aminoglycoside- resistance genes among the $31 \mathrm{~A}$. veronii isolates (94\%). However, in an earlier report, all Aeromonas spp. isolates recovered from marketed cockles harbored $a a c\left(6^{\prime}\right)-1 b$, with $\operatorname{str} A$-strB found in $41 \%$ of the isolates [43]. The recommended first-line therapeutic options for Aeromonas infections are aminoglycosides and fluoroquinolones. We identified gentamicin as an aquatic medicine that can be inoculated orally to prevent Aeromonas infection. Its appropriate use could potentially prevent the emergence of new resistant strains.

The resistance phenotypes varied among isolates. The pMDR of $A$. hydrophila, which was resistant to three or more classes of antimicrobials, was $18.6 \%$; this was lower than that observed in a previous study conducted on tilapia where $64 \%$ of isolates were resistant to six to eight drugs [31] and that in 95 motile pMDR aeromonads isolated from freshwater [46]. Additionally, multi-antibiotic resistant Aeromonas spp. isolates harbored a tripartite AheABC efflux pump, and the use of phenylalanine-arginine- $\beta$-naphthylamide contributed to intrinsic resistance [51]. Among the Aeromonas spp. isolates identified as pMDR, the most common resistance was against oxytetracycline (100\%). Oxytetracycline is among the most commonly used antibiotics in humans and animals, and these results are consistent with those of a previous study [52]. The distribution of strains resistant to oxytetracycline has increased with the global use of antibiotics; the emergence of pMDR strains complicates the selection of available therapeutics.

This study provides eight putative ECVs for classifying WT and NWT isolates; however, the findings should not be used as Aeromonas-pathogen-treatment guidelines. These ECVs were derived from one laboratory; therefore, it is essential to evaluate different sources and a large number of isolates for reliably establishing ECVs for each Aeromonas strain [53]. The results from this study can be used as a foundation to establish clinical breakpoints for each Aeromonas strain. Additionally, it is necessary to study the NWT bacterial transcriptome and the mechanism of antibiotic resistance transmission between humans and fish to determine the cause of resistance acquisition.

\section{Materials and Methods}

\subsection{Collection and Isolation of Aeromonas spp.}

Aeromonas spp. isolates were collected between 2008 and 2020 from eight Korean provinces (Chungbuk, Chungnam, Gyeongbuk, Gyeongnam, Gyeonggi, Jeonbuk, Jeonnam, and Gangwon), with $43 A$. hydrophila isolates recovered from $A$. japonica $(n=25)$, Carassius carassius $(n=3)$, S. asotus $(n=3)$, Cyprinus carpio nudus $(n=2)$, Sebastes schlegelii $(n=2)$, and others $(n=8)$; and $33 A$. veronii isolates recovered from $A$. japonica $(n=13), C$. carpio nudus $(n=9), C$. carassius $(n=4), S$. asotus $(n=3)$, and others $(n=4)$ (Figure 7$)$. The bacterial strains are listed in Tables S2 and S3. The fish species were sampled from among seemingly healthy, clinical-subclinical, and moribund fish that differed by the year and region of collection. Samples were taken from the lesions, kidneys, and spleens of fish. All experiments were performed in accordance with Directive 2010/63/EU of the European Parliament and the Council (22 September 2010) on the protection of animals used for scientific purposes. Aeromonas spp. isolates were grown on Aeromonas agar (MB cells, Los Angeles, CA, USA), incubated at $37^{\circ} \mathrm{C}$ for $24 \mathrm{~h}$. Presumptive aeromonad colonies showing typical dark-green opaque color with a dark center were chosen and subjected to molecular identification. Genomic DNA was extracted from a single colony using a QIAmp DNA blood mini kit (Qiagen, Milan, Italy), according to the manufacturer instructions. DNA concentration and purity were quantified using a Nano Drop R 2000 spectrophotometer (Thermo Fisher Scientific, Waltham, MA, USA) DNA was stored at $-80^{\circ} \mathrm{C}$ until use. Aeromonas spp. isolates 
were stored at $-80{ }^{\circ} \mathrm{C}$ in tryptic soy broth (Merck, Kenilworth, NJ, USA) supplemented with $20 \%$ glycerol until further use.

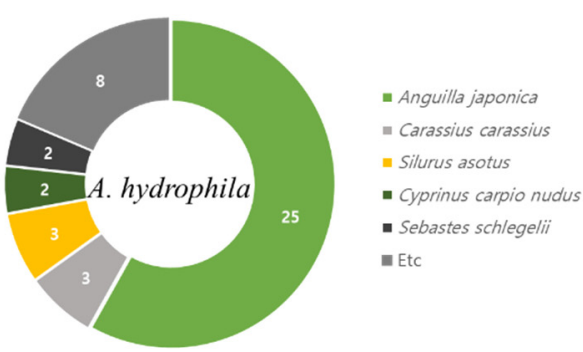

(B)

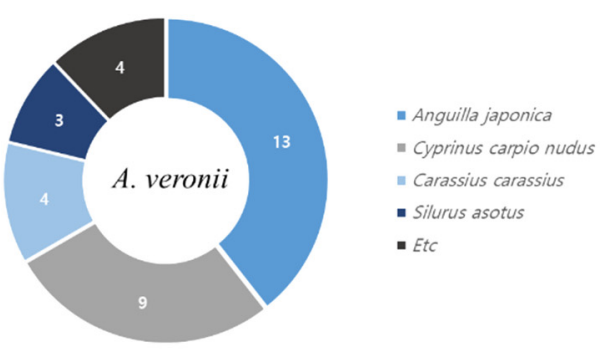

Figure 7. Isolated strains used in this study. These included (A) 43 Aeromonas hydrophila and (B) 33 Aeromonas veronii strains isolated from various aquatic animals from Korea.

\subsection{Molecular Identification}

Bacterial identities were confirmed using PCR with two different primer sets for amplification and sequencing of $16 \mathrm{~S}$ rRNA and gyrB. The $16 \mathrm{~s}$ rRNA gene (1361 bp) was amplified and sequenced using specific primers (27F: 5'-AGA GTT TGA TCM TGG CTC AG-3' and 1387R: 5'-GGG CGG WGT GTA CAA GGC-3'). gyrB (904 bp) was used as the housekeeping gene to further identify species (gyrB 3F: $5^{\prime}$-TCC GGC GGT CTG CAC GGC GT-3' and gyrB 14R: 5'-TTG TTC GGG TTG TAC TCG TC-3') [54]. The PCR reaction mix at $50 \mu \mathrm{L}$ contained $5 \mu \mathrm{L}$ of $10 \times$ Ex Taq buffer, $4 \mu \mathrm{L}$ dNTP mixture $(2.5 \mathrm{mM}$ each), 10 pmol of each primer, $0.25 \mu \mathrm{L}$ Ex Taq DNA polymerase (Takara, Shiga, Japan), $10 \mathrm{ng}$ DNA template, and sterile purified water. The reaction conditions were as follows: initial denaturation at $95^{\circ} \mathrm{C}$ for $3 \mathrm{~min}$, followed by 30 cycles of denaturation at $98^{\circ} \mathrm{C}$ for $10 \mathrm{~s}$, $55{ }^{\circ} \mathrm{C}$ for $30 \mathrm{~s}$, and extension at $72{ }^{\circ} \mathrm{C}$ for $30 \mathrm{~s}$, with a final extension at $72{ }^{\circ} \mathrm{C}$ for $7 \mathrm{~min}$. The PCR products were confirmed through sequence analyses (Bionics, Seoul, Korea); the strains were verified based on the reference sequences accessed from GenBank (https: / / www.ncbi.nlm.nih.gov/genbank/) (accessed on 5 May 2021).

\subsection{Antimicrobial Susceptibility Test}

Antimicrobial susceptibility tests were performed according to the broth microdilution method described in the CLSI guidelines VET04 [17,18]. The antimicrobial agents for Aeromonas spp. isolates are licensed and commonly used for aquatic animals in Korea [38]. The MICs of $43 \mathrm{~A}$. hydrophila and $33 \mathrm{~A}$. veronii isolates were tested using Sensititre CAMPY2 and KRAQ1 plates (Trek Diagnostics System, Cleveland, OH, USA). MICs for erythromycin (0.03-64 mg L $\left.{ }^{-1}\right)$, florfenicol $\left(0.03-64 \mathrm{mg} \mathrm{L}^{-1}\right)$, and gentamicin $\left(0.12-32 \mathrm{mg} \mathrm{L}^{-1}\right)$ were tested using CAMPY2; and those for doxycycline $\left(0.25-64 \mathrm{mg} \mathrm{L}^{-1}\right)$, enrofloxacin (0.03-32 $\left.\mathrm{mg} \mathrm{L}^{-1}\right)$, flumequine $\left(0.12-128 \mathrm{mg} \mathrm{L}^{-1}\right)$, neomycin $\left(0.5-64 \mathrm{mg} \mathrm{L}^{-1}\right)$, and oxytetracycline $\left(0.25-256 \mathrm{mg} \mathrm{L}^{-1}\right)$ were tested using KRAQ1. Isolates were cultured on tryptic soy agar for $24 \mathrm{~h}$ at $28^{\circ} \mathrm{C}$, after which a suspension was prepared in sterile saline solution, adjusted to $0.5 \mathrm{McF}$ arland standard, and diluted to reach a final inoculum concentration of $5 \times 10^{5} \mathrm{CFU} / \mathrm{mL}$ using a Nephelometer ${ }^{\circledR}$ (V3011, Thermo Scientific, Roskilde, Denmark) to standardize inoculum density/turbidity. Microplates were incubated at $28^{\circ} \mathrm{C}$ for $24 \mathrm{~h}$ for $A$. hydrophila and A. veronii. MICs were defined as the lowest drug concentrations that inhibited growth, compared to that in the drug-free growth control. E. coli ATCC 25922, A. salmonicida subsp. salmonicida ATCC 33658, and E. faecalis ATCC 29212 were included in the susceptibility test as QC strains. Recently, additional MICs of ECVs were made available for A. hydrophila in the updated CLSI guidelines [18]. We compared the A. hydrophila and A. veronii isolates among WT and NWT populations, according to the CLSI guidelines and the provisional ECVs proposed in this study. 


\subsection{Determination of Provisional ECVS}

ECVs were calculated using two methods: NRI [55] and ECOFFinder [56]. The NRI method is a fully automatic and freely available Excel spreadsheet calculator (last updated in 2019; http:/ / www.bioscand.se/ nri) (accessed on 3 May 2021). The ECOFFinder method (v.2.1; last updated in 2020) is available from the EUCAST website (https: / / www.eucast. org/mic_distributions_and_ecoffs) (accessed on 3 May 2021). In this study, ECV determination was based on the distribution of antimicrobial MICs for each drug against $A$. hydrophila

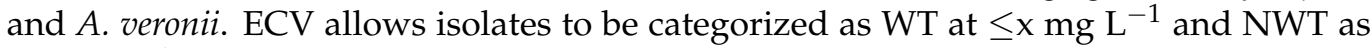
$>$ x mg L ${ }^{-1}$. A $99.0 \%$ cut-off was applied, which means that approximately $99.0 \%$ of the WT MIC distribution was less than the identified ECV. pMDR was defined as resistance to more than three antimicrobial agents, classes, or subclasses of antimicrobial categories [57]. The number of pMDR Aeromonas was determined for eight antimicrobial agents (doxycycline, enrofloxacin, erythromycin, florfenicol, flumequine, gentamicin, neomycin, and oxytetracycline) in the clinical samples.

\subsection{Terminology}

When referring to the categorization of isolates based on their susceptibility, we followed the recommendations, which suggested that when isolates are categorized by applying ECVs, the terms "sensitive" and "resistant" should not be used [58]. WT is defined, for a fully susceptible species, as the absence of acquired- and mutational-resistance mechanisms to the drug, and NWT is defined as the reduced susceptibility to the presence of an acquired- or mutational- resistance mechanism to the drug. However, when referring to studies that used the term "resistant", we did not change their terminology. The CLSI uses the abbreviation "ECV" for epidemiological cut-off values, whereas EUCAST uses the ECOFF. This study used "ECV" to prevent confusion when comparing the ECOFF values using the two analytical methods.

\subsection{Analysis of ARGs}

We tested 43 A. hydrophila and 33 A. veronii isolates for the presence of ARGs, including tet $A$, tet $B$, tet $D$, and tet $E$ for tetracycline; cat and floR for phenicol; qnr-type pentapeptide proteins encoded by $q n r A, q n r B$, and $q n r S$ for quinolone; and $\operatorname{str} A-\operatorname{str} B$ and $a a c\left(6^{\prime}\right)-1 b$ for aminoglycosides (Table 7). The primers used to detect these genes were selected from previous studies. The PCR cycling conditions were as follows: $94{ }^{\circ} \mathrm{C}$ for $5 \mathrm{~min}$, followed by 35 cycles of $95^{\circ} \mathrm{C}$ for $30 \mathrm{~s}$, annealing for $30 \mathrm{~s}$ at different temperatures, $72{ }^{\circ} \mathrm{C}$ for $30 \mathrm{~s}$, and $72{ }^{\circ} \mathrm{C}$ for $5 \mathrm{~min}$. The PCR products were separated using electrophoresis on a $1 \%$ agarose gel and purified for sequencing. Sequence identities were confirmed using the sequence information in the NCBI database (on https:/ / www.ncbi.nlm.nih.gov/) (accessed on 22 June 2021). 
Table 7. PCR primers to detect ARGs.

\begin{tabular}{|c|c|c|c|c|c|}
\hline Class & Primer & Sequence $\left(5^{\prime}-3^{\prime}\right)$ & $\mathrm{AT} *\left({ }^{\circ} \mathrm{C}\right)$ & $\operatorname{Size}(b p)$ & Reference \\
\hline \multirow{8}{*}{ Tetracycline } & tet $A-\mathrm{F}$ & GCG CTN TAT GCG TTG ATG CA & \multirow[b]{2}{*}{53} & \multirow[b]{2}{*}{387} & \multirow[b]{2}{*}[59]{} \\
\hline & tet $A-\mathrm{R}$ & ACA GCC CGT CAG GAA ATT & & & \\
\hline & tetB-F & CTC AGT ATT CCA AGC CTT TG & \multirow{2}{*}{58} & \multirow{2}{*}{400} & \multirow{2}{*}[60]{} \\
\hline & tetB-R & CTA AGC ACT TGT CTC CTG TT & & & \\
\hline & tetD-F & GCG CTN TAT GCG TTG ATG CA & \multirow[b]{2}{*}{50} & \multirow[b]{2}{*}{484} & \multirow[b]{2}{*}[59]{} \\
\hline & tetD-R & CCA GAG GTT TAA GCA GTG T & & & \\
\hline & tetE-F & GCG CTN TAT GCG TTG ATG CA & \multirow{2}{*}{50} & \multirow{2}{*}{246} & \multirow{2}{*}{ [59] } \\
\hline & tetE-R & ATG TGT CCT GGA TTC CT & & & \\
\hline \multirow{4}{*}{ Phenicol } & cat-F & AGC GCA ACG TCC TCT ATC AC & \multirow{2}{*}{55} & \multirow{2}{*}{378} & This study \\
\hline & cat-R & TGT CGT CGT CAA AGC GGT AG & & & (PMU05929.1) \\
\hline & floR-F & GCC CGC TAT GAT CCA ACT CA & \multirow[b]{2}{*}{55} & \multirow[b]{2}{*}{289} & This study \\
\hline & floR-R & AAG GCC GTA GAT GAC GAC AC & & & (QEV84023.1) \\
\hline \multirow{6}{*}{ Quinolone } & $q n r A-\mathrm{F}$ & AGA GGA TTT CTC ACG CCA GG & \multirow{2}{*}{56} & \multirow[b]{2}{*}{580} & \multirow{2}{*}{ [61] } \\
\hline & $q n r A-\mathrm{R}$ & TGC CAG GCA CAG ATC TTG AC & & & \\
\hline & $q n r B-F$ & GAT CGT GAA AGC CAG AAA GG & \multirow{2}{*}{53} & \multirow{2}{*}{496} & \multirow{2}{*}[61]{} \\
\hline & $q n r B-\mathrm{R}$ & ACG ATG CCT GGT AGT TGT CC & & & \\
\hline & $q n r S-F$ & GCA AGT TCA TTG AAC AGG GT & \multirow{2}{*}{56} & \multirow{2}{*}{428} & \multirow{2}{*}[61]{} \\
\hline & qnrS-R & TCT AAA CCG TCG AGT TCG GCG & & & \\
\hline \multirow{5}{*}{ Aminoglycoside } & $\operatorname{str} A-s t r B-F$ & TAT CTG CGA TTG GAC CCT CTG & \multirow{3}{*}{55} & \multirow{3}{*}{538} & \multirow{3}{*}{ [62] } \\
\hline & strA-strB-R & CAT TGC TCA TCA TTT GAT CGG & & & \\
\hline & & 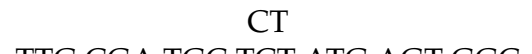 & & & \\
\hline & $\operatorname{aac}\left(6^{\prime}\right)-1 b-\mathrm{F}$ & TTG CGA TGC TCT ATG AGT GGC & \multirow{2}{*}{55} & \multirow{2}{*}{482} & $662]$ \\
\hline & $a a c\left(6^{\prime}\right)-1 b-\mathrm{R}$ & CTC GAA TGC CTG GCG TGT TT & & & [63] \\
\hline
\end{tabular}

${ }^{*} \mathrm{AT}$; annealing temperature.

\section{Conclusions}

This is the first study to establish $\mathrm{ECV}_{\mathrm{NRI}}$ and $\mathrm{ECV}_{99}$ values for eight antimicrobials against $43 \mathrm{~A}$. hydrophila and $33 \mathrm{~A}$. veronii isolates recovered from aquatic animals in Korea and to detect ARGs in Aeromonas strains. A total of $89.2 \%$ A. hydrophila isolates and $75.8 \%$ A. veronii isolates were classified as NWT against oxytetracycline; they harbored tet genes; Aeromonas spp. isolates predominantly carried tet $E$, followed by tet $A$. Additionally, the distribution of floR and $q n r S$ was prevalent in NWT isolates, whereas no aac $\left(6^{\prime}\right)-1 b$ or $\operatorname{str} A$ $s t r B$ was detected in the $31 A$. veronii isolates. The emergence of antibiotic-resistant strains of Aeromonas spp. reduces the choice of currently available therapeutic agents and it could lead to prolonged Aeromonas infections. Therefore, these results can potentially help aquaculture managers and researchers alleviate Aeromonas infections in aquaculture systems and raise awareness of the appropriate use of antimicrobials in aquaculture. Furthermore, these findings encourage the application of vaccination or herbal therapy, to reduce antibiotic resistance and public health problems.

Supplementary Materials: The following supporting information can be downloaded at: https: / / www.mdpi.com/article/10.3390/antibiotics11030343/s1, Table S1: CLSI-approved broth microdilution MIC QC ranges determined for eight antimicrobial agents against selected reference strains; Table S2: Isolate year, fish species, disease outbreak, isolation source, and geographical location of the 43 A. hydrophila strains; Table S3: Isolate year, fish species, disease outbreak, isolation source, and geographical location of the $33 \mathrm{~A}$. veronii strains.

Author Contributions: Conceptualization, S.-J.W.; methodology, S.-J.W. and M.-G.J.; software, M.-G.J. and M.-Y.D.; validation, M.-G.J. and M.-Y.D.; formal analysis, S.-J.W. and M.-G.J.; investigation, S.-J.W. and M.-Y.D.; data curation, S.-J.W., M.-S.K., S.-D.H. and W.-J.K.; writing-original draft preparation, S.-J.W.; writing-review and editing, S.-J.W., M.-S.K., S.-D.H. and W.-J.K.; project administration, M.-S.K. All authors have read and agreed to the published version of the manuscript. 
Funding: This research was supported by a grant from the National Institute of Fisheries Science (grant No. R2022076)

Institutional Review Board Statement: Not applicable.

Informed Consent Statement: Not applicable.

Data Availability Statement: The data that support the findings of this study are available upon request from the corresponding author.

Conflicts of Interest: The authors declare no conflict of interest.

\section{References}

1. Khor, W.C.; Puah, S.M.; Koh, T.H.; Tan, J.A.M.A.; Puthucheary, S.D.; Chua, K.H. Comparison of clinical isolates of Aeromonas from Singapore and Malaysia with regard to molecular identification, virulence, and antimicrobial profiles. Microb. Drug Resist. 2018, 24, 469-478. [CrossRef]

2. Fečkaninová, A.; Koščová, J.; Mudroňová, D.; Popelka, P.; Toropilova, J. The use of probiotic bacteria against Aeromonas infections in salmonid aquaculture. Aquaculture 2017, 469, 42. [CrossRef]

3. Mazumder, A.; Choudhury, H.; Dey, A.; Sarma, D. Isolation and characterization of two virulent Aeromonads associated with haemorrhagic septicaemia and tail-rot disease in farmed climbing perch Anabas testudineus. Sci. Rep. 2021, 11, 5826. [CrossRef]

4. Sen, K.; Rodgers, M. Distribution of six virulence factors in Aeromonas species isolated from US drinking water utilities: A PCR identification. J. Appl. Microbiol. 2004, 97, 1077-1086. [CrossRef]

5. Janda, J.M.; Abbott, S.L. The genus Aeromonas: Taxonomy, pathogenicity, and infection. Clin. Microbiol. Rev. 2010, $23,35-73$. [CrossRef]

6. Abd-El-Rhman, A.M. Antagonism of Aeromonas hydrophila by propolis and its effect on the performance of Nile tilapia, Oreochromis niloticus. Fish. Shellfish Immunol. 2009, 27, 454-459. [CrossRef] [PubMed]

7. Falco, A.; Frost, P.; Miest, J.; Pionnier, N.; Irnazarow, I.; Hoole, D. Reduced inflammatory response to Aeromonas salmonicida infection in common carp (Cyprinus carpio L.) fed with $\beta$-glucan supplements. Fish. Shellfish Immunol. 2012, 32, 1051-1057. [CrossRef] [PubMed]

8. Vanden Bergh, P.; Frey, J. Aeromonas salmonicida subsp. salmonicida in the light of its type-three secretion system. Microb. Biotechnol. 2014, 7, 381-400. [CrossRef] [PubMed]

9. Wang, R.; Hu, X.; Lü, A.; Liu, R.; Sun, J.; Sung, Y.Y.; Song, Y. Transcriptome analysis in the skin of Carassius auratus challenged with Aeromonas hydrophila. Fish. Shellfish Immunol. 2019, 94, 510-516. [CrossRef]

10. Mulyani, Y.; Aryantha, I.N.P.; Suhandono, S.; Pancoro, A. Intestinal bacteria of common carp (Cyprinus carpio L.) as a biological control agent for Aeromonas. J. Pure Appl. Microbiol. 2018, 12, 601-610. [CrossRef]

11. Rasmussen-Ivey, C.R.; Figueras, M.J.; McGarey, D.; Liles, M.R. Virulence factors of Aeromonas hydrophila: In the wake of reclassification. Front. Microbiol. 2016, 7, 1337. [CrossRef] [PubMed]

12. Ramalivhana, J.N.; Obi, C.L.; Moyo, S.R. Prevalence of extended-spectrum $\beta$-lactamases producing Aeromonas hydrophila isolated from stool samples collected in the Limpopo province, South Africa. Afr. J. Microbiol. Res. 2010, 4, 1203-1208. [CrossRef]

13. Chenia, H.Y. Prevalence and characterization of plasmid-mediated quinolone resistance genes in Aeromonas spp. isolated from South African freshwater fish. Int. J. Food Microbiol. 2016, 231, 26-32. [CrossRef] [PubMed]

14. Hossain, S.; De Silva, B.C.J.; Wimalasena, S.H.M.P.; Pathirana, H.N.K.S.; Dahanayake, P.S.; Heo, G.J. Distribution of antimicrobial resistance genes and class 1 integron gene cassette arrays in motile Aeromonas spp. isolated from goldfish (Carassius auratus). Microb. Drug Resist. 2018, 24, 1217-1225. [CrossRef]

15. Aravena-Román, M.; Inglis, T.J.; Henderson, B.; Riley, T.V.; Chang, B.J. Antimicrobial susceptibilities of Aeromonas strains isolated from clinical and environmental sources to 26 antimicrobial agents. Antimicrob. Agents Chemother. 2012, 56, 1110-1112. [CrossRef]

16. Boerlin, P.; Reid-Smith, R.J. Antimicrobial resistance: Its emergence and transmission. Anim. Health Res. Rev. 2008, 9, 115-126. [CrossRef]

17. Clinical and Laboratory Standards Institute (CLSI). Performance Standards for Antimicrobial Susceptibility Testing of Bacteria Isolated from Aquatic Animals; VET03/VET04-S2.; CLSI: Wayne, PA, USA, 2014; pp. 1-42.

18. Clinical and Laboratory Standards Institute (CLSI). Performance Standards for Antimicrobial Susceptibility Testing of Bacteria Isolated from Aquatic Animals, 3rd ed.; VET04.; CLSI: Wayne, PA, USA, 2020; pp. 1-88.

19. Yao, Z.; Sun, L.; Wang, Y.; Lin, L.; Guo, Z.; Li, D.; Lin, W.; Lin, X. Quantitative proteomics reveals antibiotics resistance function of outer membrane proteins in Aeromonas hydrophila. Front. Cell. Infect. Microbiol. 2018, 8, 390. [CrossRef]

20. Li, Z.; Wang, Y.; Li, X.; Lin, Z.; Lin, Y.; Srinivasan, R.; Lin, X. The characteristics of antibiotic resistance and phenotypes in 29 outer-membrane protein mutant strains in Aeromonas hydrophila. Environ. Microbiol. 2019, 21, 4614-4628. [CrossRef]

21. Baron, S.; Granier, S.A.; Larvor, E.; Jouy, E.; Cineux, M.; Wilhelm, A.; Gassilloud, B.; Bouquin, S.L.; Kempf, I.; Chauvin, C. Aeromonas Diversity and Antimicrobial Susceptibility in Freshwater-An Attempt to Set Generic Epidemiological Cut-Off Values. Front. Microbiol. 2017, 8, 503. [CrossRef] 
22. Hayatgheib, N.; Calvez, S.; Fournel, C.; Pineau, L.; Pouliquen, H.; Moreau, E. Antimicrobial Susceptibility Profiles and Resistance Genes in Genus Aeromonas spp. Isolated from the Environment and Rainbow Trout of Two Fish Farms in France. Microorganisms 2021, 9, 1201. [CrossRef]

23. Duman, M.; Saticioglu, I.B.; Altun, S. The determination of antimicrobial susceptibility by MIC and epidemiological cut-off values and the detection of resistance genes in Aeromonas species isolated from cultured fish. Lett. Appl. Microbiol. 2020, 71, 531-541. [CrossRef] [PubMed]

24. Clinical and Laboratory Standards Institute (CLSI). Methods for Antimicrobial Dilution and Disk Susceptibility Testing of Infrequently Isolated or Fastidious Bacteria, 3rd ed.; CLSI guideline M45.; CLSI: Wayne, PA, USA, 2016; pp. 1-19.

25. Clinical and Laboratory Standards Institute (CLSI). Methods for Dilution Antimicrobial Susceptibility Tests for Bacteria That Grow Aerobically, 11th ed.; CLSI standard M07; CLSI: Wayne, PA, USA, 2018; pp. 1-13.

26. Pessoa, R.B.G.; de Oliveira, W.F.; Marques, D.S.C.; dos Santos Correia, M.T.; de Carvalho, E.V.M.M.; Coelho, L.C.B.B. The genus Aeromonas: A general approach. Microb. Pathog. 2019, 130, 81-94. [CrossRef] [PubMed]

27. Goñi-Urriza, M.; Pineau, L.; Capdepuy, M.; Roques, C.; Caumette, P.; Quentin, C. Antimicrobial resistance of mesophilic Aeromonas spp. isolated from two European rivers. J. Antimicrob. Chemother. 2000, 46, 297-301. [CrossRef]

28. Saengsitthisak, B.; Chaisri, W.; Punyapornwithaya, V.; Mektrirat, R.; Klayraung, S.; Bernard, J.K.; Pikulkaew, S. Occurrence and antimicrobial susceptibility profiles of multidrug-resistant aeromonads isolated from freshwater ornamental fish in Chiang Mai province. Pathogens 2020, 9, 973. [CrossRef] [PubMed]

29. Č́ižek, A.; Dolejská, M.; Sochorová, R.; Strachotová, K.; Piačková, V.; Veselý, T. Antimicrobial resistance and its genetic determinants in aeromonads isolated in ornamental (koi) carp (Cyprinus carpio koi) and common carp (Cyprinus carpio). Vet. Microbiol. 2010, 142, 435-439. [CrossRef] [PubMed]

30. Limbu, S.M.; Zhou, L.; Sun, S.X.; Zhang, M.L.; Du, Z.Y. Chronic exposure to low environmental concentrations and legal aquaculture doses of antibiotics cause systemic adverse effects in Nile tilapia and provoke differential human health risk. Environ. Int. 2018, 115, 205-219. [CrossRef] [PubMed]

31. Nhinh, D.T.; Le, D.V.; Van, K.V.; Huong Giang, N.T.; Dang, L.T.; Hoai, T.D. Prevalence, Virulence Gene Distribution and Alarming the Multidrug Resistance of Aeromonas hydrophila Associated with Disease Outbreaks in Freshwater Aquaculture. Antibiotics 2021, 10, 532. [CrossRef]

32. Piotrowska, M.; Przygodzińska, D.; Matyjewicz, K.; Popowska, M. Occurrence and variety of $\beta$-lactamase genes among Aeromonas spp. isolated from urban wastewater treatment plant. Front. Microbiol. 2017, 8, 863. [CrossRef]

33. Goñi-Urriza, M.; Capdepuy, M.; Arpin, C.; Raymond, N.; Caumette, P.; Quentin, C. Impact of an urban effluent on antibiotic resistance of riverine Enterobacteriaceae and Aeromonas spp. Appl. Environ. Microbiol. 66, 125-132. [CrossRef]

34. Skwor, T.; Shinko, J.; Augustyniak, A.; Gee, C.; Andraso, G. Aeromonas hydrophila and Aeromonas veronii predominate among potentially pathogenic ciprofloxacin-and tetracycline-resistant Aeromonas isolates from Lake Erie. Appl. Environ. Microbiol. 2014, 80, 841-848. [CrossRef]

35. Zdanowicz, M.; Mudryk, Z.J.; Perliński, P. Abundance and antibiotic resistance of Aeromonas isolated from the water of three carp ponds. Vet. Res. Commun. 2020, 44, 9-18. [CrossRef] [PubMed]

36. Tekedar, H.C.; Arick, M.A.; Hsu, C.Y.; Thrash, A.; Blom, J.; Lawrence, M.L.; Abdelhamed, H. Identification of antimicrobial resistance determinants in Aeromonas veronii strain MS-17-88 recovered from channel catfish (Ictalurus punctatus). Front. Cell. Infect. Microbiol. 2020, 10, 348. [CrossRef] [PubMed]

37. Shin, S.W.; Shin, M.K.; Jung, M.; Belaynehe, K.M.; Yoo, H.S. Prevalence of antimicrobial resistance and transfer of tetracycline resistance genes in Escherichia coli isolates from beef cattle. Appl. Environ. Microbiol. 2015, 81, 5560-5566. [CrossRef] [PubMed]

38. National Institute of Food and Drug Safety Evaluation (NIFDS). National Antimicrobial Resistance Surveillance on the Domestic and Imported Meat and Fishery Products; NIFDS: Cheongju, Korea, 2019; pp. 1-161.

39. National Institute of Fisheries Science (NIFS). Aquatic Medicine Catalog; NIFS: Busan, Korea, 2020; pp. 12-102.

40. McIntosh, D.; Cunningham, M.; Ji, B.; Fekete, F.A.; Parry, E.M.; Clark, S.E.; Zalinger, Z.B.; Gilg, I.C.; Danner, R.D.; Johnson, K.A.; et al. Transferable, multiple antibiotic and mercury resistance in Atlantic Canadian isolates of Aeromonas salmonicida subsp. salmonicida is associated with carriage of an IncA/C plasmid similar to the Salmonella enterica plasmid pSN254. J. Antimicrob. Chemother. 2008, 61, 1221-1228. [CrossRef] [PubMed]

41. Gordon, L.; Cloeckaert, A.; Doublet, B.; Schwarz, S.; Bouju-Albert, A.; Ganière, J.P.; Le Bris, H.; Le Flèche-Matéos, A.; Giraud, E. Complete sequence of the floR-carrying multiresistance plasmid pAB5S9 from freshwater Aeromonas bestiarum. J. Antimicrob. Chemother. 2008, 62, 65-71. [CrossRef]

42. Sezer, A.D.; Akbuğa, J.; Baş, A.L. In vitro evaluation of enrofloxacin-loaded MLV liposomes. Drug Deliv. 2007, 14, 47-53. [CrossRef]

43. Dahanayake, P.S.; Hossain, S.; Wickramanayake, M.V.K.S.; Heo, G.J. Prevalence of virulence and antimicrobial resistance genes in Aeromonas species isolated from marketed cockles (Tegillarca granosa) in Korea. Lett. Appl. Microbiol. 2020, 71, 94-101. [CrossRef]

44. Schmidt, A.S.; Bruun, M.S.; Dalsgaard, I.; Larsen, J.L. Incidence, distribution, and spread of tetracycline resistance determinants and integron-associated antibiotic resistance genes among motile aeromonads from a fish farming environment. Appl. Environ. Microbiol. 2001, 67, 5675-5682. [CrossRef] [PubMed]

45. Koksal, F.; Oguzkurt, N.; Samastı, M.; Altas, K. Prevalence and antimicrobial resistance patterns of Aeromonas strains isolated from drinking water samples in Istanbul, Turkey. Chemotherapy 2007, 53, 30-35. [CrossRef] 
46. Borella, L.; Salogni, C.; Vitale, N.; Scali, F.; Moretti, V.M.; Pasquali, P.; Alborali, G.L. Motile aeromonads from farmed and wild freshwater fish in northern Italy: An evaluation of antimicrobial activity and multidrug resistance during 2013 and 2016. Acta Vet. Scand. 2020, 62, 1-8. [CrossRef]

47. Igbinosa, I.H. Antibiogram profiling and pathogenic status of Aeromonas species recovered from Chicken. Saudi J. Biol. Sci. 2014, 21, 481-485. [CrossRef] [PubMed]

48. Rawal, I.; Joshi, H.; Chaudhary, L. Isolation, identification, and antibiotics resistance of Aeromonas spp. from lakes of Udaipur (Rajasthan), India. Asian J. Pharm. 2016, 10, 132-136. [CrossRef]

49. Lin, H.T.; Bavro, V.N.; Barrera, N.P.; Frankish, H.M.; Velamakanni, S.; van Veen, H.W.; Robinson, C.; Borges-Walmsley, M.I.; Walmsley, A.R. MacB ABC transporter is a dimer whose ATPase activity and macrolide-binding capacity are regulated by the membrane fusion protein MacA. J. Biol. Chem. 2009, 284, 1145-1154. [CrossRef]

50. Azzam-Sayuti, M.; Ina-Salwany, M.Y.; Zamri-Saad, M.; Yusof, M.T.; Annas, S.; Najihah, M.Y.; Liles, M.R.; Monir, M.S.; Zaidi, Z.; Amal, M.N.A. The prevalence, putative virulence genes and antibiotic resistance profiles of Aeromonas spp. isolated from cultured freshwater fishes in peninsular Malaysia. Aquaculture 2021, 540, 736719. [CrossRef]

51. Hernould, M.; Gagné, S.; Fournier, M.; Quentin, C.; Arpin, C. Role of the AheABC efflux pump in Aeromonas hydrophila intrinsic multidrug resistance. Antimicrob. Agents Chemother. 2008, 52, 1559-1563. [CrossRef] [PubMed]

52. Yu, J.; Ramanathan, S.; Chen, L.; Zeng, F.; Li, X.; Zhao, Y.; Lin, L.; Monaghan, S.J.; Lin, X.; Pang, H. Comparative transcriptomic analysis reveals the molecular mechanisms related to oxytetracycline-resistance in strains of Aeromonas hydrophila. Aquac. Rep. 2021, 21, 100812. [CrossRef]

53. Smith, P.; Kronvall, G. How many strains are required to set an epidemiological cut-off value for MIC values determined for bacteria isolated from aquatic animals? Aquac. Int. 2015, 23, 465-470. [CrossRef]

54. Yanez, M.A.; Catalán, V.; Apráiz, D.; Figueras, M.J.; Martínez-Murcia, A.J. Phylogenetic analysis of members of the genus Aeromonas based on gyrB gene sequences. Int. J. Syst. Evol. Microbiol. 2003, 53, 875-883. [CrossRef]

55. Kronvall, G. Normalized resistance interpretation as a tool for establishing epidemiological MIC susceptibility breakpoints. $J$. Clin. Microbiol. 2010, 48, 4445-4452. [CrossRef] [PubMed]

56. Turnidge, J.; Kahlmeter, G.; Kronvall, G. Statistical characterization of bacterial wild-type MIC value distributions and the determination of epidemiological cut-off values. Clin. Microbiol. Infect. 2006, 12, 418-425. [CrossRef] [PubMed]

57. Magiorakos, A.P.; Srinivasan, A.; Carey, R.B.; Carmeli, Y.; Falagas, M.E.; Giske, C.G.; Harbarth, S.; Hindler, J.F.; Kahlmeter, G.; Olsson-Liljequist, B.; et al. Multidrug-resistant, extensively drug-resistant and pandrug-resistant bacteria: An international expert proposal for interim standard definitions for acquired resistance. Clin. Microbiol. Infect. 2012, 18, 268-281. [CrossRef] [PubMed]

58. Silley, P. Susceptibility testing methods, resistance and breakpoints: What do these terms really mean? OIE Rev. Sci. Tech. 2012, 31, 33-41. [CrossRef] [PubMed]

59. Jun, L.J.; Jeong, J.B.; Huh, M.D.; Chung, J.K.; Choi, D.L.; Lee, C.H.; Jeong, H.D. Detection of tetracycline-resistance determinants by multiplex polymerase chain reaction in Edwardsiella tarda isolated from fish farms in Korea. Aquaculture 2004, 240, 89-100. [CrossRef]

60. Akinbowale, O.L.; Peng, H.; Barton, M.D. Diversity of tetracycline resistance genes in bacteria from aquaculture sources in Australia. J. Appl. Microbiol. 2007, 103, 2016-2025. [CrossRef]

61. Cattoir, V.; Poirel, L.; Rotimi, V.; Soussy, C.J.; Nordmann, P. Multiplex PCR for detection of plasmid-mediated quinolone resistance qnr genes in ESBL-producing enterobacterial isolates. J. Antimicrob. Chemother. 2007, 60, 394-397. [CrossRef]

62. Sunde, M.; Norström, M. The genetic background for streptomycin resistance in Escherichia coli influences the distribution of MICs. J. Antimicrob. Chemother. 2005, 56, 87-90. [CrossRef]

63. Park, C.H.; Robicsek, A.; Jacoby, G.A.; Sahm, D.; Hooper, D.C. Prevalence in the United States of $a a c\left(6^{\prime}\right)-I b-c r$ encoding a ciprofloxacin-modifying enzyme. Antimicrob. Agents Chemother. 2006, 50, 3953-3955. [CrossRef] 